\title{
ARCHIVE
}

Stanistaw Ossowski, 1897-1963, was one of the most versatile and influential figures in Polish sociology. His lifetime interests revolved around the issues of nation, but his output in the fields of theory of aesthetics and social classes is more extensive. Can one refer to a theory of nation by Ossowski? Of the six meanings of 'sociological theory' discerned by Robert Merton, ${ }^{1}$ Ossowski's approach was closest to explication of notions, which he deals with in his best-known text in the field of national studies, Analiza socjologiczna pojęcia ojczyzny [A sociological analysis of the notion of homeland], with his proposed definition:

A certain territory may become a homeland only if there occurs a group of people who relate to it in a certain fashion, and shape its image in a certain manner. ... Homeland only exists in the subjective reality of social groups. ${ }^{2}$

Let us note that such definition is groundbreaking as it precedes the classical Benedict Anderson's definition of nation as imagined community. ${ }^{3}$

Within the same essay, Ossowski has differentiated between private and ideological homeland. This contribution has been reflected in his pioneering 1947 essay dealing with the issues of regional and national bond in Opole Silesia, published in this issue of APH for the first time in an English version. One of the few studies this sociologist founded on field research, this treatise originally crowned a series of Polish monographs on nation. ${ }^{4}$

Ossowski has identified a few key subjects that made attempts at mobilising favourable attitude of the respective communities toward a national ideology: primarily, the German state and the Polish state. Between those two were families, which, joining various national-religious organisations,

${ }^{1}$ Robert K. Merton, Social Theory and Social Structure (3rd revised and enlarged edn., Glencoe, Ill., 1959).

2 Stanisław Ossowski, 'Analiza socjologiczna pojęcia ojczyzny', in idem, Dzieła, iii: Z zagadnień psychologii społecznej (Warsaw, 1967), 203.

${ }^{3}$ Benedict Anderson, Imagined Communities: Reflections on the Origin and Spread of Nationalism (2nd extended edn., London and New York, 1991).

${ }^{4}$ Józef Chałasiński, 'Antagonizm polsko-niemiecki w osadzie fabrycznej "Kopalnia” na Górnym Śląsku. Studium socjologiczne', Przegląd Socjologiczny, iii, 1-2 (1935); Józef Obrębski, Problem etniczny Polesia (Biblioteka 'Spraw Narodowościowych', 26, Warsaw, 1936); Krystyna Duda-Dziewierz, Wieś matopolska a emigracja amerykańska. Studium wsi Babica powiatu rzeszowskiego (Biblioteka Socjologiczna Polskiego Instytutu Socjologicznego, 3, Warsaw, 1938). 
formed a 'stem of Polishness'. For them, Polishness, or things Polish, were associated with the supreme values: religion, honour, and dignity. Around the 'stem of Polishness' existed circles of people whose adoption of national ideology was weaker, ending with individuals representing, in Ossowski's words, a 'nominalism in matters national', deprecating or renouncing any form of national ideology.

According to Ossowski, on the plane of individual's awareness, ideology can be perceived as superimposed, or can be recognised as one's own - and perceived as such; finally, ideology can be instinctivised, repositioned as part of the sphere of habitus and controlling human actions beyond the individual's consciousness. On the other hand, a national ideology can be rendered up-to-date, more or less frequently: it may be a solemn or everyday value.

The moment a national ideology becomes adopted and internalised, thus becoming one's own, it creates a variety of 'stereotypes' and 'individual images', as Ossowski puts it - or, 'cognitive representations', using the language of our contemporary sociologists. Ossowski was one of the first social psychologists to have focused on these developments, showing that a nation may be of a 'nominal' or 'adjectival' nature. As he talked to the inhabitants of 'Gietczyn', it became apparent for him that the category of 'Pole', which is usually nominal, in grammar terms (one is or is not a Pole), 'appears gradable' at that location, as "one can be a Polok [dial., Pole] to a larger or lesser extent." Ossowski's theory was pioneering with respect to analyses proposed by modern psychologists.

Ossowski has not exhibited his discovery. On the one hand, he limited his considerations to borderland areas, whereas any member of a nation, including anyone of those living in a nationally homogeneous territory, may think of it in prototypical/adjectival categories. On the other hand, Ossowski ought to have approached the categorial and the prototypal take as a dichotomy, rather than in terms of distinction. Thus, he would have certainly noticed that any member of a nation can shift from the categorial into prototypal recognition, and backwards. 
Stanisław Ossowski

\section{THE REGIONAL BOND AND THE NATIONAL BOND IN OPOLE SILESIA: SOME ASPECTS OF RELEVANCE}

\section{I \\ REGIONAL COMMUNITY}

In my differentiation between 'private homeland' and 'ideological homeland', argued on elsewhere, ${ }^{1}$ a national territory was borne in mind with reference to the latter, as the study I am referring to had originally stemmed from my research on modern nationalism. Our definition of ideological homeland is now broader, though, referring to an area to which the individual is bound not through his or her direct, personal experience with regard to such territory, and the habits developed by way of such experience - but rather, through his or her membership of, or affiliation with, a certain community that is somehow assigned to the territory in question. The role of personal factors in the individual's relation to his or her ideological homeland is a matter of interferences between the private and the ideological homeland.

A modern nation is not the only form of such community. Ideological homeland was possessed by territorial communities of varied sorts, with which the idea of nation, in its modern meaning, would not quite go. In Europe as it stands today, one may also speak of ideological homelands of regional communities: there is, potentially, a room for a regional homeland between a private homeland and a national territory. Where the bond linking an individual with his/her regional homeland also links this individual through participation in a community, a private homeland is not the case.

There are various approaches to the notion of 'region'. It is frequently understood as a geographical unit delineated based on the

\footnotetext{
1 'Analiza socjologiczna pojęcia ojczyzny’, Myśl Wspótczesna (1946), no. 2.
} 
terrain features or economic criteria. In the sense proposed in our present considerations - that is, in a sociological meaning - region is a correlative of regional community. The latter is defined as a territorial community, with a larger or lesser sense of its own singularity - whilst not considering itself a nation; to put it otherwise, such a community's members would not try to ascribe their community the attributes typical of nation. A community of the type being described is usually a constituent of some national community. Members of a regional community - the Podhale or Kurpie people, Burgundians or Gasconians - may simultaneously consider themselves patriots of their region and patriots of their national homeland. Yet, it happens in certain somewhat godforsaken areas of Europe, or in some borderlands with a complex history record, that their dwellers would not reach beyond their regional bond, as they have no national sentiment, as the phrase once went.

A third possibility is a very strong sense of regional peculiarity combined with antagonistic attitude toward the state the region is part of - with separatist tendencies, and an ideology with political postulates being its component, coming into prominence. Leaders of such a community endeavour to apply the pattern of national community to it, and tackle the matters in line with the model of struggle for national liberation. The moment as from which one can recognise the reshaping of a regional community of this kind as a nation is a rather relative thing. Around 1880, there was a regionalistic movement spreading in Catalonia, propagating the Catalonian culture and language within the Spanish homeland. After 1890, 'single Catalonian homeland' became a slogan that was picked up louder and louder. In a case like this, the dispute whether we have actually to do with a regional group or a nation taking shape often follows the viewpoints of the group struggling for national emancipation, on the one hand, and of the wider community that defends its holdings and assets, opposing the idea to quit one of its 'regions', on the other.

In contrast to a national community of the sort found to be dominant in Continental Europe, save for the Soviet Union, regional community, as has been said, may form a component of a broader community - a nation or another regional community (regions within regions; regions, large and small). From a sociological point of view, there is no reason not to consider as regions those 
great areas of the interwar Polish Republic - such as former Galicia, Congress Kingdom, or Poznań Province (Provinz Posen) - whose populaces preserved their sense of singularity which had once developed resulting from the frontier cordons set in the national bondage period. A poznaniak (inhabitant of Greater Poland) would very strongly feel his (her) distinctiveness in relation to a galicjak (inhabitant of Galicia) or kongresowiak (inhabitant of Congress Kingdom), in spite of his/her Polish patriotism. Smaller regions were emerging within these great regional communities, based on a remoter past and folkloristic differences, and thereby better corresponding with the colloquial use of the term 'region': Podhale people, Cracovians, Kurpie people, Księżaks (i.e. Łowicz people), or Kashubians.

The origins of distinctive regional identity can be diverse. Its source may be topographic conditions causing the region's isolation, to some extent, from its surrounding area (Corsica; Zeeland islands in the Netherlands; Scottish Highlands areas inhabited by separate clans, intersected with fiords, lakes, and mountain ranges) or imposing a peculiar type of economic life and neighbourly contacts (Podhale, Hutsul Land, Polesia, Kurpie, Coal Basin). It may stem from a separate political history: the region might have been a separate state in the past, or belonged, in various periods, to different political formations. Spain emerged resulting from a merger of seventeen kingdoms, one county and two seignories; the peculiarities that differed the populations of these small states before the unification have left, in various cases, lasting marks until today. At the time it belonged to France, Alsace-Lorraine differed from the other French provinces with the memory of its past political associations with the German Reich; in the period it was part of the Reich, the province sensed its distinctiveness against the other German countries - owing, among other factors, to the memory of its past within the limits of the French Kingdom and the French Republic. Along with other factors, peculiar political fortunes informed the sense of individuality among inhabitants of the Yugoslavian provinces of Bosnia, Banat, Sanjak, Macedonia, not to name Croatia or Dalmatia. "We were with Austria, then we nearly were with Bohemia, then we were with Poland, then, with Germany, and now, Poland again", a local of the Cieszyn-area town of Ustron once complained to me. "We would like to know, once forever, that we are somewhere for good": we, meaning residents of Cieszyn Silesia, in this particular case. 
There are instances, particularly in case of smaller areas, that the reasons for the sense of separateness ought to be traced in historical conditions of a different kind - such as Łowicz Land's affiliation with the Gniezno Archbishopric, or the royal estates [królewszczyzny] making the local peasants' social life take a different course than in the areas where it was shaped by direct dependence on the landowner.

Apart from all such situations where the singularity of a regional group stems from the regional territory's geographical or political distinctiveness, we have to take into account, as the source of sense of regional distinction, certain cultural properties of the region's inhabitants which prove to be momentous for the social life but do not have to be genetically related with the topographic characteristics, or historical past, of the area. What I primarily have in mind is a separate language or religion. Distinction as to language is an important factor of regionalism in various borderland provinces of France: Brittany, Flanders, Alsace, Niçard Country, Basque Country, Roussillon. In Poland, the Kashubian dialect, although not separating Kashubians from Kociewie people or Mazurians with a barrier of incomprehensibility, plays a similar part, to an extent. Let us notice that separate language can be a factor of regional separateness even if used by a part of the region's inhabitants - as in Brittany, for instance; in such cases, language can be an element of the local culture, respected also by those who never use it.

In some individual cases, various factors of regional individuality can mutually cooperate. Still, a region can owe its autonomy to a mixture of certain features, of which each relates it to a different territorial whole. Group separateness can in fact ensue from a group's parallel or subsequent membership in two different, larger communities. Belgian Flemings are associated with the Walloons through the political past and Catholicism; language is their link to the Dutch. The Prussian Mazurians were associated through language with the northern Masovia of their indigenous Poland, whilst the political affiliation and denomination made them united with the Germans. Religion separated them not only from the Mazurians from behind the cordon but also from the Polish inhabitants of the Chelmno Land (Kulmerland), with whom they were associated politically between 1772 and 1919, and from Varmia people with whom they have been connected through common political vicissitudes for 175 years now. If the Ukrainians of Galicia can be said to have formed a regional 
community with a strong sense of singularity, it is so because the political developments and the Catholic religion have bound them to the West, whilst the language and the Greek rite have made them associated with the East.

II

A VILLAGE ON THE ODER RIVER

We have now arrived in Opole Silesia, a dozen-or-so kilometres northwest of Opole. The area is the one of the former Regency of Opole [1815-1945], thus being part of what once was the Upper Silesia - but we are situated much closer to Wroclaw than Katowice. Clearly, in economic terms, this lower part of Upper Silesia has not much more in common with what we are accustomed to associate with the name 'Upper Silesia' than the vast areas of a farmers' America set against the images of industrial metropolises that come to a European's mind at the sight of the 'U.S.' symbol. This is an agricultural Silesia, featuring big villages built in brick, narrow roads and balks, each square yard of the land being intensely exploited, no pasture or fallow. The horizon is closed with a skyline of forests; on serene days, a remote contour of the Sudetes mountains is seen bluing, looking to the south-west.

We are within the limits of the 1921 plebiscite area; to be precise, in its part that was finally assigned to the Germans. It is not even the border zone: a distance of at least 50 kilometres separates us from the PolishGerman frontier line that cut apart the Upper Silesian area in 1921.

On the right-hand side of the Oder River, the western language border from the pre-war time is set, a dozen-or-so kilometres away. Although we are in a borderland of the language area, the villages located on this strip of land by the river were populated by Poles, with a more or less considerable admixture of immigrant Germans - seemingly, of yesterday, more or less. According to a German map compiled in 1906 by Paul Langhans, ${ }^{2}$ the German people in that area, up the language frontier on the right-hand side of the Oder, amounted between 0 and 25 per cent. The German colonisers inhabiting the local Polish villages in the latter half of the eighteenth century were

${ }^{2}$ Nationalitäten-Karte der Provinz Schlesien (Gotha, 1906) [editorial footnote; hereinafter: ed.]. 
largely Polonised much in the way their peers in the central Poland were. This is attested by the gravestones in rural cemeteries, featuring German names and Polish inscriptions; the other characteristic element is German names of some Polish patriots in the rural areas. The German villages set up there after the Seven Years' War had been preserved until the last war. "It's Fryc der Grosse [Frederick the Great] who has mucked the country up so", one of the local husbandmen told me.

These German colonies were, in parallel, Protestant islands within a Catholic country. After all, Catholics began flowing into them with time; as it seems, those were, mainly, Poles from the neighbouring villages. I cannot tell to what extent the numerical data I have found for Finkenstein Colony (after a Prussian minister's name), founded in 1773 and called Brzezie by Polish locals, may be deemed characteristic:

\begin{tabular}{ccc}
\hline Year & Catholic & Protestant \\
\hline 1783 & - & 109 \\
\hline 1857 & 18 & 245 \\
\hline 1887 & 49 & 220 \\
\hline 1902 & 94 & 227 \\
\hline 1912 & 107 & 230 \\
\hline 1929 & 140 & 200 \\
\hline
\end{tabular}

I have gathered the relevant sociographic material during my three weeks' stay in Opole Silesia, with my assistant Jan Strzelecki, in August 1945. We spent most of the time in one of the largest villages in Opole Land; let us assume the village's name was 'Giełczyn'. ${ }^{3}$ The research was subsidised by the Polish Sociological Institute.

Albeit filled with intense effort, the sojourn was too short to formulate a profile of the social structure of the village, venture some conclusions regarding the degree of prevalence of ideological attitudes to be covered further on. Save for certain concrete calculations, the numerical estimations I have received from the inhabitants of 'Giełczyn' I talked to ought to be approached as expression of these people's beliefs or perhaps desiderates, in some cases. I have found considerable discrepancies appearing in individual cases in this

${ }^{3}$ The village's real name is Dobrzeń Wielki (German: Groß Döbern) [ed.]. 
respect: the 'Giełczyn' members of the Association of Poles before the war, in the most successful period, amounted to 500, according to one account, or more than 100, as somebody else said. A troop of insurgents formed in 'Giełczyn' had 200 members, or perhaps 150, including 70 dwellers of the village. ${ }^{4}$ The number of pupils at the Polish school in the last years before the war was twenty, or seven. In this very latter case, the number was verified based on a personal enumeration obtained from one of the then-students. Time constraint would not have let me check the other figures analogously.

Owing to quite advantageous conditions of the research, the period of our stay sufficed for finding out about the characteristic attitudes of a certain milieu of the area's rural populace, note and record certain interesting sociological phenomena, and realise what form is assumed by regional and national bond issues when applied to this particular area. I approach this essay primarily as posing the issues that could form a basis for further study.

Speaking of advantageous conditions of doing the research, what I have in mind is that we won trust of one of the most respected farmers in 'Giełczyn', to which end my earlier acquaintance with his son was helpful. Then, of importance was a positive presumption aroused among the village dwellers by the title of university professor; similarly, lack of class-related scruples; ease of talking to a newcomer on a social basis; finally, there were hopes of various people wronged by the sudden change of the overall conditions that this 'professor from Warsaw' could give them good advice or his personal support. Hence their tending towards talking rather long; albeit the conversation aiming at a defined purpose was often driven by some diplomatic design, it would soon after become propelled by the interviewee's need to unbosom before someone who was listening kindly and attentively. This is how the unmasking of my incognito I was first so concerned about turned out betimes to be effectively beneficial.

'Giełczyn' is a large village which together with its adjacent hamlets numbered three thousand and a few hundred inhabitants

${ }^{4}$ In reality, the troop had eighty people, incl. thirty-one from 'Giełczyn'; however, there were ninety-five insurgent conspirers in the locality. The troop that came out of 'Giełczyn' was composed of unmarried members. I quote these numbers based on a list of names luckily preserved by the troop's leader; I had an opportunity to use this list this June. 
before the war. It is located by the track of the main Silesian railroad, at the Opole-Wroclaw line, within a few-kilometre-long strip between a forest and the bed of the Oder. The settlement has two Catholic churches: one in the village's centre, a large brick church, built in a recent time, the other wooden, by the woods, a legend-shrouded indulgence place. The rather small area (975 ha) squeezed between the forest, the Oder and the neighbouring rural area would not have sufficed to feed the large settlement - if not for the railway station, the forest, and a few industrial establishments (a shipyard on the Oder, a small knitwear factory, a sawmill, and two brickyards), offering gain to the landless and smallholders.

There are forty-plus farmers (gburs) in the village, all of them independent people, all of them self-employed; of those, less than a half are holders of dozen-or-so-hectare lands, forming the village's aristocracy. There are over 250 smallholder farmers. The remainder (some $60 \%$ of the population) are holders of landless or almost landless farms and tenant farmers. The social structure of a village on the Wisłok, or elsewhere, from the time of pre-war joblessness ought not to be projected on this settlement on the Oder, though: there, the stratification into well-to-do peasants (kmiećs), smallholder or little-land farmers (zagrodniks) and tenant farmers (komorniks) had a different economic sense.

In 'Giełczyn', the farmers value their autonomy, but this is not to say they would consider themselves economically privileged in relation to the smallholders, who basically earn a living with the railway or the industry. In particular, the wives or daughters of some of the farmers speak with a hint of jealously of the wives of those people who work on the railway or go out elsewhere to earn money: with no large farm of their own, those women do not work as much as the farmers' wives do; they can keep their hands clean, and dress nicely. Conflicts with small farmers and workers or farmhands were incited at the elections for the Communal Council; the rich famers would not succeed to carry their wójt or soltys (village mayor) candidate. Besides, conflicts occurring between gburs and zagrodniks, with the ensuing long years of litigation, revolved in the past around the village pastures.

Otherwise, the mentality of these husbandmen is somewhat different than that of well-off kmiećs from Lesser Poland (Małopolska) or central Poland. Characteristically, a few farmers from 'Giełczyn' 
I talked about economy with assumed a resolute stance against introducing free trade, given the present-day conditions: not until there are goods in abundance, products should be sold in a food-stamp system: small portions for everybody.

The farming populace, farm owners in the first place, belong in most cases to families settled from time immemorial in 'Giełczyn' or its vicinity. This is attested by the tombstones at the cemetery where the same surnames are found reappearing; and, by the relationships between the neighbours, who know each other's ancestors. On establishing the Erbhoffs ${ }^{5}$ in the Nazi period, they reportedly found that the farmstead of a certain Młynek in the neighbour village had been with the Młynek family for seven hundred years. There has never been a manor; before the emancipation of the serfs, 'Giełczyn' formed part of a monastic estate. ${ }^{6}$

The image of 'Giełczyn' based on my individual experience is one seen with the eyes of those farmers, in the first place, as it is this very group I had dealt with most of all. This group stands out very clearly against the social structure of the village. Casual encounters and talking to people on their way back from a church fair would not satisfactorily counterbalance these farmer-related aspects. In particular, I had no opportunity during this short stay to become acquainted with the viewpoint of the local proletariat. Based on the share of vote for the socialist and communist option reckoned in the 1932 parliamentary election, this group must have occupied an important position in this settlement's life.

\section{III}

POLISHNESS AND CATHOLICISM

'Giełczyn' has been a Catholic settlement for ages. According to the local parish chronicle, published by the Rev. Roch Scheitza (probably, 'Siejca') ${ }^{7}$ in 1934 , the confessional composition of the populace within the last fifty years before the war saw the following fluctuation:

${ }^{5}$ I.e. inherited indivisible farmsteads.

${ }^{6}$ The proprietor being the Premonstratene monastery of Czarnowąsy [ed.].

${ }^{7}$ Roch Scheitza, Kronika parafii Wielko Dobrzyńskiej w zarysie (Wrocław, 1934). Actually, the Polish spelling of the compiler's name was 'Szajca' [ed.]. 


\begin{tabular}{cccc}
\hline Year & Catholic & Protestant & Jewish \\
\hline 1887 & 2,108 & 28 & 10 \\
\hline 1891 & 2,155 & 19 & 10 \\
\hline 1895 & 2,185 & 4 & 2 \\
\hline 1897 & 2,200 & 18 & 8 \\
\hline 1902 & 2,113 & 15 & 12 \\
\hline 1912 & 2,441 & 31 & 4 \\
\hline 1929 & 3,041 & 45 & 8 \\
\hline
\end{tabular}

The leaping consecutive numbers of Protestant members of the local community seem to indicate that this small denominational group has apparently been formed of aliens. As reported by the residents I talked to, just a dozen-or-so German families had lived in 'Giełczyn' before the plebiscite - virtually, all of them clerks or teachers.

'Giełczyn' has issued a certain number of professionals: a few teachers, most of whom moved to the Polish Silesia following the plebiscite; a construction foreman; a German officer, who, as they say, supplied Polish partisans operating near Warsaw with weapons and ammunition; a physician; finally, of the younger generation, a sculptor, presently assistant lecturer with the Academy of Fine Arts in Krakow, and his colleague, a doctor of philosophy from the Jagiellonian University. But it was the post of priest that attracted the intellectually gifted locals the most. According to the parish chronicle, between the beginning of the nineteenth century and the year 1934, there were twenty secular priests and four seminarists, who died before finally ordained, originally from 'Giełczyn'; apart from these, there were some monks and nuns. The priesthood vocation was influenced by the family background: there was a family that issued four priests within a hundred years, another one fostered three clergymen, and yet another, five. During the war, an old man died in 'Giełczyn' who was a Polish patriot nicknamed 'saint': he had fathered four priests and three 'virgins' (nuns).

As of 1934, there were twelve Catholic associations active in 'Giełczyn': (1) a Rosary Fraternity; (2) Sacred Heart of Jesus Fraternity; (3) [Congregation of the Nursing Sisters of] the Order of St Francis; (4) St Francis Xavier Association; (5) Association of Christian Mothers; (6) a Marian Congregation of Girls; (7) an Infant Jesus 
Association; (8) a Men's Apostolate; (9) a St Boniface Association; (10) a Men's Association; (11) a 'St [Charles] Borromeo' Reading Room (with 200 volumes available); and, (12) a Katholischer Frauenbund, set up after Hitler's coming to power.

How about the national sentiment among the 'Giełczyn' locals? The opinions heard in this respect in 1945 from the local farmers need being approached quite cautiously: after all, Polish identity was being verified at that moment. Based on recognising somebody a Pole, his and his family lot was determined: either they would be allowed to stay at their [brick] cottage with their possessions, or made go, destitute, go live a wandering life, preceded perhaps by months of 'doing penance' at a camp. How can one wonder at the 'herd' solidarity inciting those not threatened by displacement to make efforts to defend the patriotism of their endangered neighbours? Ambition came into play as well: the newcomers from central Poland and, all the more so, immigrants from Volhynia or Lvov Land contemptuously treated the Polishness of Silesians who intersperse their speech with German words and wear German-style dress; educated under the Nazis, their children every so often do not understand Polish, on top of that. Given these circumstances, the trend to exaggerate any symptom of Polishness on the part of those who "defended their Polish identity over the six hundred years and now, the Germans expelled, are called 'Germans'”, appears justifiable.

The landlord I stayed with differentiates between the three 'sorts' of Poles among the locals: (i) those who "appeared as Poles till the end"; (ii) those who were 'genuine' Poles, and were members of the Association of Poles before the war, brought up their children in the Polish environment, but feared to display their Polish identity in the time of persecution; (iii) those who were dependent on their German employer and thus had to behave as Germans. "Who worked for a German and would not purport to be a German, could not gain progress", says Mr. 'Gwiozda', and old man. This is true with e.g. railwaymen; a Pole could only work with a pickaxe. Having joined a German organisation, he could get promoted. If he joined the partai [Nazi party], before the war, he was not worth much; but during the war the pressure was very strong, so a decent man could also join the partai, when timid or burdened with a family. Quite a few partaimen rendered considerable services to Poles by warning them of what the German police intended. 
Against the locals' common stories claiming an undisputed Polishness of 'Giełczyn', and against the old German nationality statistics, the results of the Reichstag election of November 6, 1932, are striking. In this last election before Hitler came to power, the German Catholic 'Centre' got 442 votes, the Communists 228, SocialDemocrats 141, National Socialists 148, the German-Nationals 46, and the Polish Party 134.

This ticket makes us aware of the existence of four ideological currents in the community of 'Giełczyn': Catholicism; social radicalism; Polishness; and, Germanness. The Catholic candidates (Centre and Polish Party) received over a half of the total vote, but the German Catholic list received over three times more votes than the Polish list. Taking into account the ethnic composition of 'Giełczyn' populace and the fact that all the Catholic associations within the parish were Polish fellowships, and realising that a part of the vote cast for the Communists and the Social-Democrats came from the Germans, all the votes for the German-Nationals and almost all for National Socialists were cast by Germans, we have to assume that the largest number of Polish votes in 'Giełczyn' were received by the German 'Centre'.

Requested to explain this fact, the more reliable farmers refer to the pressure from the Nazi party, which in November 1932 was preparing for taking power and exhorted to vote openly: "We are not ashamed of the votes we're casting", the Hitlerites said. The pressure was perhaps not so strong at the time yet, if we see the communists and socialists receiving a 32 per cent vote on their lists, quite a significant outcome with a rural commune. I therefore believe that a factor incomparably more important than the pressure on open voting was the canvassing of the priests: they had Polish surnames, said Polish sermons, and heard confessions in Polish - but considered it the interest of Catholicism that the most powerful Catholic option, i.e. the Centre, be supported by them. The Catholics could choose between two lists, the Centre and Polish. But if the issue of nationality was not part of the picture from a Catholic point of view, it was the prestige of a party known to be of higher importance in the Reichstag that easily gained prevalence. 


\section{IV \\ WITHIN THE LIMITS OF THE REICH \\ AFTER THE VERSAILLES TREATY}

I regret I do not have sufficient materials that would allow me to get a closer acquaintance with a specific process of polarisation of national attitudes after the division of Silesia. The defeat of Germany in 1918, the plebiscite, the Silesian Uprisings are the occurrences that have transferred the national issue in Silesia to a completely new plain, compared to the previous times, opening for the Polish movement certain at-allunexpected horizons. After the plebiscite defeat suffered by the Opole region, it was hard to resume the psychical attitudes with which the Silesians efficiently opposed the Germanising Kulturkampf policy before the previous war, crooning repeatedly to their mugs of beer:

Comrades, oh, comrades, let's drink now together,

And our family, don't forget it ever. ${ }^{8}$

Although the protection of the Geneva Convention and the PolishGerman agreements extended now to the Polishness of Opole Silesia, and communication with Poland was facilitated, it was realised that international care would not last forever; the freshly roused political expectations were buried forever by the deed of 1921, the Polish people believed. The post-plebiscite atmosphere of abjuration was reflected in a reduced Polish vote for the Communal Council and the Parliament. Germany, having learned its lesson with the plebiscite experience, embarked - less drastically than before, formally observing their accepted obligations, but much more systematically - on gradual elimination of Polishness in its eastern territory. These intents were expressly worded in a book by Karl Keller, Chief Councillor of State with the Prussian statistical office:

We do not know if there can occur in a future a political situation of the sort allowing to put forth one wish or the other. Therefore, it is not a needless

8 'Family' [rodzina] means here, obviously enough, '(the) family land', or 'compatriots at large'. In any case, this ditty was quoted to me when in 'Giełczyn' as a patriotic song from before WWI. There were incidents, as I was told by my landlord, that during the uprising, some fathers considered themselves Germans whilst their sons joined the insurgents' ranks to serve the Polish side; according to this man, this resulted from educational impact of the Polish clubroom. 
labour to give evidence, over and over again, to the German character of these lands, which, albeit left for us by the peace treaties, have been the subject of claims laid by our enemies in 1918/19. ${ }^{9}$

In 'Giełczyn', both the Association of Poles and the Youth Association, which still in the last years before the war amounted, reportedly, to some fifty members, demonstrated a rather considerable activity in organising cultural events, amusements and, sometimes, trips to Poland, with support from the Polish Government. Apart from the analogous German associations, there existed a Polish Singing Society and a Society for Amateur Performing. Once established, in 1924, the Polish school saw around sixty children applying, of whom more than a half withdrew resulting from persuasions from the German teachers and other Germans. As of 1929, three Catholic German schools in 'Giełczyn' numbered 597 schoolchildren and nine teachers, whilst the Polish school had twenty-one pupils and one teacher. In 1937/8, the same school only had seven children attending, and was eventually closed down in the following year, resulting from too small number of enrollers. ${ }^{10}$ The neighbouring village did not manage to open a Polish school even in the most favourable period as the group of potential enrollers was found too scarce - albeit the minimum sufficient, as per the Geneva Convention, to demand a minority school in Silesia was a mere twelve. In such conditions, sending the child to a Polish school meant more than an expression of the family's attachment to their native language. One of the farmers whose children belonged to the last group of seven told me that he had considered maintaining a Polish school, in defiance of the overall pressure exerted by the Germans, a morally weighty thing, even though a handful of children would have been ready to attend.

In Polish Silesia, the German Volksbund was awaiting the day of retaliation, counting on a war to come and preparing to this great

${ }^{9}$ Karl Keller, Die Fremdsprachige Bevölkerung im Grenzgebieten des Deutschen Reiches (Begleitschrift zum Kartenwerk: Sprachenatlas der deutschen Grenzgebiete, Berlin, 1929), 62. Quoted after: Emil Kuroński ['Polacy w Niemczech w urzędowych spisach ludności'], Sprawy Narodowościowe, xii, 4/5 (1938), 386.

${ }^{10}$ More on the methods of pressure exertion on Polish parents against sending their children to Polish schools, and the methods of intimidating Polish people in the last years before WWII, is said in the Memorial of the Association of Poles in Germany of 2nd June 1938, sent to the Minister of Interior of the Reich and Prussia, cf. Sprawy Narodowościowe, xii, 3 (1938), 328. 
moment. The Association of Poles of Opole Silesia could count, at most, at an opportunity to sing Jeszcze Polska nie zginęta [Poland has not yet perished; the Polish national anthem] or Deutschland über alles before [Polish] Minister Beck and German Minister, as it happened during the Association's Berlin convention in 1935.

There is one more important circumstance to mention: the area was cleared of patriotic activists. After the plebiscite, a considerable portion of the most patriotically inclined priests, teachers, and social activists moved to Poland. Those who remained no more perceived around them a support comparable to that before the plebiscite. Worse even, they could see they were in a country that has been deserted by their own people - those 'most own'; a country where, in national terms, the situation could only go for the worse as years passed after the Versailles Treaty.

If, therefore, someone 'appeared as a Pole' still in the Nazi time, without an intent to emigrate eastwards or northwards, they would probably do it only for honorary reasons, or owing to a sense of solidarity with a certain group of co-residents. The point was obviously not about an ethnic group which "defended their Polish identity over the six hundred years" but, instead, quite a petty group of individuals professing a different type of ideology, alongside Catholicism.

\section{$\mathrm{V}$ \\ A NOUN, OR AN ADJECTIVE?}

Let us ponder for a while on the meaning of the word 'Pole' [Polak] as uttered by the residents of 'Giełczyn' and its surrounding villages. Such a 'semantic' digression will perhaps free us of certain confusions ensuing from projecting on that milieu the concepts elaborated in the areas where the national life took shape on the soil of state tradition.

Let us first of all notice, then, that when applied to the local people, the term 'Pole' does not have the normal nominal meaning we have got accustomed to: one that identifies a member of a national community whose membership is not gradable, and virtually cannot be reconciled with participation in any other national community. ${ }^{11}$

${ }^{11}$ I neglect here a situation where so-called 'second homeland' is referred to: normally perceived as exceptional, such a situation is admissible in emigration milieus, rather than in a borderland area. 
The nominal meaning of Polak is not alien to Opole-region rural people, as long as it refers to arrivals from the former Polish cordon. "Polok you are likewise, but you wouldn't quote that I be closed [in the prison], is it?", an old woman said to me, one whose Polish identity could not be called into question: she got disturbed with her own sincerity, having complained to me about the wrongs done to the local populace by the newly-come 'Poloks'.

The Prussian statistics refrained from introducing nationality columns before 1939, using linguistic columns (Muttersprache) instead, whereas there was a 'bilingual' category, which initially was to pertain to exceptional cases. As the related instructions had it:

Every man possesses a single mother tongue. Only scarce individuals possess two mother tongues. Such instances occur at times, however, with persons whose parents are of different mother tongues.

In practice, the bilingual category was devised for reducing the number of Poles whilst in parallel offering refuge to all those who would not be willing to declare their individual nationality in clear terms.

Following the Versailles Treaty, the bilingual category began to expand terrifyingly: by 1933, those who admitted a double mother tongue, Polish and German, amounted in the Reich to more than two-and-a-half in excess of the number of unilingual Poles. The instructions still claimed that "as a general rule, every man possesses a single mother tongue"! This point was further clarified, to be sure, which enabled to more unrestrainedly interpret the notion of 'mother tongue'12 and facilitated to attain such glamorous a result.

In 1938, along with the categories of citizenship (Staatsangehörigkeit) and the native language, ethnicity (Volkszugehörigkeit) was introduced in the forms in use; the examples attached encouraged the formfillers to declare their nationality as German, even though the native tongue would be Polish (regardless of the Staatsangehörigkeit). ${ }^{13}$

As it becomes apparent, Prussian censuses suggested no clear 'species-related' division into Poles and Germans. No such suggestion can be found in reminiscences from the time of the plebiscite, either, although in that period the choice between the two options was an

${ }^{12}$ As a language "in which (one) thinks and likes to use it most with his family members and at home" (italicised by S.O.).

${ }^{13}$ The census was shifted to 1939. 
acute one, without a compromising category of 'bilingual', and in spite of the fact that the acuteness of the split was sealed with blood. Regardless of the fact that one could abstain from voting, thus staying neutral, the two camps fighting each other were of a different orientation: those who followed Germany and those who followed Poland, rather than forming two groups of people different as to 'species': Germans and Poles. Apart from alien people: alien Germans, of whom there were many, and alien Poles, a less numerous group, German and Polish troops were joined by the same local people. In some cases, those who were soldiers with a Polish troop spoke worse Polish, and spoke Polish rarer, than those who served with a German troop. ${ }^{14}$

Those among the locals who managed the plebiscite action; those who excelled in the Uprising; those who stayed there after the plebiscite disaster and under hopeless conditions afterward never ceased claiming that Silesia was Polish; those who despite all the admonishments sent their children to the Polish school, propagated membership with the Association of Poles, imported Polish books from behind the cordon, were by no means perceived by the local milieu as Poles: they were 'great Poloks', 'enormous Poloks', or 'severe [meaning, roughly, 'greatest'] Poloks'. These phrases, common in the area, use the term 'Polok' in a clearly adjectival sense, making it gradable: one can be greater or smaller a 'Polok' - that is, one in whose life a certain ideology plays a greater or smaller role. In this adjectival sense, the word 'Polok' is, rather, an equivalent of 'nationalist', obviously without the political tint the notion is added where 'national parties (or factions)' operate.

Telling a story of his struggles with the Kożdon-ites ${ }^{15}$, an old socialist in Cieszyn Silesia calls himself and his friends, socialists like himself, 'nationalists': for him, anyone who feels bound to Polish national community, rather than just with his Cieszyn-Silesian compatriots, is a nationalist. The term 'nationalist' appears here to indicate the reach of a social bond someone is willing to participate in; yet, it is not equivalent with 'member of a national community' - 'Pole',

14 This state of affairs is found reflected in an expressive anecdote recorded by Jan Strzelecki in another village in the northern Opole Land; hopefully, this anecdote will be reported in his study.

${ }^{15}$ I.e. followers of Józef Kożdoń [Koždoň] (1873-1949), leader of the Cieszyn Silesia's autonomy movement [ed.]. 
in this case, as it is understood in Warsaw or Cracow. Apart from the areas where diverse national ideologies clash against one another within regional groups, members of a national community - at least in case they are not sociologists - do not comprehend their participation in such a community in a way close to Renan's approach. ${ }^{16}$ When somebody is qualified as a Pole, Frenchman or Italian, we normally do not ask about his or her ideology. Ideology as a criterion of nationality comes to the fore in certain unique situations, where one has to do with a denationalisation process.

Back with 'Giełczyn': as has been said, the word Polok, if my perception of its timbre, based on my talks with the locals, is correct, may have a 'species-related' meaning - analogous to the one normally associated by us with words such as 'Frenchman', 'Italian', or 'Albanian': it is used in its nominal sense then, whilst mostly applying to people outside Opole Land. Or, its meaning is close to that given to the word 'nationalist' by the aforementioned socialist from the vicinity of Cieszyn. In the latter case, the difference is that in the Cieszyn region, 'nationalist' [narodowiec] has apparently a stronger group-bound tint (denoting a member of a team that has opposed another group, the Kożdon-ites), and thus is not quite gradable. Polok, in turn, when used in Cieszyn Silesia in the latter identified meaning, is a more individual qualification; tending to be used with quantitative adjectives, it is gradable, and clearly adjectival.

Obviously, the adjectival meaning of the word Polok is a certain function of the nominal meaning: a 'grand Polok' is one who recognises the need to stand in solidarity with those Poloks from the former cordon, and is ready to bear sacrifices in the name of such solidarity.

VI

\section{CONSERVATIVE CUSTOM VERSUS IDEOLOGICAL STANCE}

The categorisation of the local Poles into three 'sorts', according to my landlord's concept, means a classification by the degree to which Polish identity has been manifested: thus, an instance of behavioural classification. The degree and method of manifesting Polishness is in those circumstances dependent on the role the national affairs play

${ }^{16}$ Ernest Renan, Qu'est-ce qu'une nation? Conférence faite en Sorbonne, le 11 mars 1882 (Paris, 1882) [ed.]. 
in somebody's consciousness - but it also depends on some other factors, such as economic independence, personal courage, or sense of personal dignity.

In case we are interested in social attitudes manifested in the ways these people behave, and in the talks with them; if we are interested in the issue of national and regional bond, then we will have to differentiate within the area of 'Giełczyn' and its surrounding villages two categories of Polishness. The difference between them is not about the degree: coming into play are the different social stances. Hence, two different meanings can be given to the notion of 'Polishness' in this particular case: ethnical, and ideological.

I have mentioned the polarisation appearing in the national attitudes after the plebiscite. The materials I have are too narrow for me to find to what extent this polarisation ensued from the plebiscite failure and whether the term 'polarisation' would not suggest too sever a division, compared to the reality. It however seems that the living conditions in Opole Land, since the division of Silesia, were of the sort that conscious cultivation of Polishness, which before WWI did not actually stigmatise anyone in a grievous manner - even in case it meant more than attachment to one's familiar tradition - now displayed a clearly ideological stance. This stance determined one's sentimental attitude to the blood spilled for the Polish cause in the Uprising, was decisive for one's attitude toward Poland as an independent state - the attitude that could bring a Reich citizen closer to the limits of high treason. In the first place, it was an active stance, an attitude of people who marched against the current of their day and, unless they intended to emigrate to Poland, against the guidelines of reason. Hence, it severely dissented from the stances of all those for whom attachment to their familiar tradition resulted, most of all, from their conservative passiveness.

That this singularity was felt quite clearly, is testified by the name 'great Polok', related to such ideological Polishness. The said name, encountered by me in 'Giełczyn' quite often, was proudly accepted by the great Poles themselves, whilst it was reportedly used, at times, by the Germans as an invective (Grosspole). 


\section{VII \\ THE 'STEM OF POLISHNESS'}

The group of those for whom Polishness was an ideological matter or, sometimes, the matter of a 'lifetime task' - or, in any case, a sphere associated with the sense of one's individual value - was rather scarce; the same is true for those who did not leave Opole Land after the division of Silesia. Talking to the locals, I was given a dozen-or-so concrete names of 'great Poloks' among the present-day 'Giełczyn' dwellers. As has been seen, the local Polish school had twenty-one pupils, as versus 597 children attending the German schools, as of 1929 (the year which can be deemed rather reliable in terms of assessment of national attitudes, as it is a few years distant from the stormy time of the plebiscite, with still a few years to go before Hitler came to power). I was quoted a rough number of twenty pupils of 'Giełczyn', who studied with the Polish gymnasium [high school] in Bytom ${ }^{17}$ within the dozen-or-so years of the school's existence. In the periods when participation did not imply any hazard whatsoever, the Association of Poles and the Youth Association were joined by some owing to social reasons (the inn, burnt down during the war, was the Polish merrymaking venue). If we were able to determine the number of active and passive members of these organisations, our picture would probably not have been considerably modified.

To my mind, the number of twenty-one pupils might be indicative only: there are brothers and sisters among these children, which reduces the number of families sending their kids to the Polish school. But, among the 'great Poles' are such who in 1929 did not have kids of school age. As Mr. Strzelecki has learned, in the neighbouring, much smaller village, the one that could not procure a Polish school, only three farmers did not put up the Nazi flag during the war. (After the defeat of France in 1940, the wife of one of these farmers broke down and bought a flag, but eventually did not display it.)

The 'stem of Polishness', as my landlord put it - let us name him a certain 'Marczyk' - was formed in 'Giełczyn' of a few people, or a few families. Mr. 'Marczyk' himself was one of these people, in the first place. His homestead in the hamlet, not less than a kilometre off

17 This was one of the two (if I am not mistaken) Polish gymnasia in the eastern borderland of Prussia in the interwar period (the other having been set up in Kwidzyn). 
the village, is nice and well equipped with farm and household appliances. His possession includes 15 hectares of land, in eight pieces. Since his father and then on 'Marczyk' himself bought out the decent pieces, he would not agree to joining farmlands. With its bullet prints from the Uprising time, when it was shelled by an Orgesch troop, ${ }^{18}$ his one-storey brick house brings to one's mind the cottage of Maciek Dobrzyński. ${ }^{19}$ His daughters repeatedly wanted to cover these marks, but the father tends to them as a precious keepsake; likewise, he has not allowed to take out a bullet which has been sticking until now in the window frame. In the garden stands a cross with the inscription Pod Twoja Obrone (Beneath Thy Protection), in Polish, featuring an icon of Our Lady of Częstochowa. During the war, the Germans several times ordered that the Polish inscription be removed. The farmer responded he had the figure erected to commemorate his lucky return from the war; he had obtained a permit from the Kreisamt to have the inscription displayed and he would not remove it - and if the authorities were so willing, they could do it on their own. The gendarme found that no law which would order the removal of Polish inscriptions on statues was in place yet; he suggested it would be better for the farmer to have the inscription obliterated.

I mention these details as the locals' conduct with respect to Polish inscriptions in their habitations and gardens was symptomatic. Some, fearing to leave the Polish inscription as it was, and not willing to obliterate it, would cover them with paper or planks. Although the inscriptions in question were in most cases religious in content, the resistance against obliterating them was not necessarily motivated by national considerations. The same is true about keeping the icons of Our Lady of Częstochowa. This particular representation was doubly persecuted by the Nazis: for racial reasons, as die Schwarze Madonna; and, due to ethnic reasons, as the Madonna of Częstochowa.

'Marczyk' was the founder and patron of the local Polish school in 'Giełczyn'; he moreover founded a 'Rolnik' ['Farmer'] cooperative, a Bank Rolniczy ['Farmers' Bank'], and the newspaper Nowiny

${ }^{18}$ I.e. one of the paramilitary hit squads of Captain Georg Escherich (Organisation Escherich).

${ }^{19}$ Maciek Dobrzyński, a nobleman turned into a peasant, leader of the local petty nobles, is a character in Adam Mickiewicz's Pan Tadeusz. Maciek's abject 'manor' bore traces of numerous attacks; a cannonball lay by its gate "since the Swedish [Deluge] time" (i.e. mid-17th c.) [ed.]. 
['News'], issued in Opole until 1938. He remarks that these allegedly apolitical organisations, the cooperative and the bank, were actually political; showing me a photograph of members of the bank's supervisory board, he pointed out that only three of them had not served time in a lager [Nazi concentration camp].

During the Nazi time, even when the war was on, my landlord never responded with a 'Heil Hitler!' to a Nazi's salute. The same was true of the other 'great Poles', he maintains. He would never raise his hand in the Nazi way, at no public gathering during the war. Once, at a meeting, the man next to him pulled his hand out of his pocket and had it half-raised. A brother of 'Marczyk's' was deported during the war to Auschwitz, and was killed there. 'Marczyk' himself was seriously under threat. In spite of that, he offered shelter for a few weeks to a young man from his village, a Jagiellonian University student, who was chased by the Gestapo. "He was scared, and scared we were", 'Marczyk's' wife says; "but, what you could do then!". I had an opportunity to witness a meeting of that once-student, Pieter, now a philosophy doctor, with the 'Marczyk' family - a moment quite moving in its simplicity.

Right before the war, 'Marczyk' was sued at the Sondergericht ("Hitler out-jockey'd such courts still before the war"). He was taken to court by a certain M., "a partai-man, ktak [dial., 'swede' or, poss., 'turnip'], renegade". The contention was about whether Silesia belonged to Poland in the past, or just to Bohemians; besides, my landlord said bad things about the Nazi instructions concerning Erbhoffs [inherited farms]. 'Marczyk' admitted his involvement in the Silesia dispute, saying that he had been told about the Polish past of Silesia by his German teacher; and, he did not own up to criticising the Erbhoff concept. He was eventually released by the judge-man.

A father of eight, 'Marczyk' supplied students for the Polish school throughout its existence. His youngest daughter, who also first attended this very school, switched to a German school after it was closed down and had to join the $\mathrm{BDM}^{20}$ in the war years. Since she would not turn up at rallies and her father paid the sztrafa [dial., penalty]; the charge was high: initially, 5 marks, it later turned into $20 \mathrm{mk}$ and $50 \mathrm{mk}$.

${ }^{20}$ I.e. the Bund Deutscher Mädel. 
Among the most ardent 'great Poles' was the local master blacksmith, a seventy-year-old man bearing a German name, ${ }^{21}$ of a quite multiple 'Giełczyn' family that has issued several 'great Poles'. In his young years, this man made his journeyman's trip across Germany; he worked in Hamburg and Magdeburg, but returned to his home village as a zealous Pole. His master at the time, a German, harassed him for this Polishness and called him Franchyshshek Maka, ironically Polonising his German surname. During the plebiscite and the Uprising, the blacksmith actively took part in the actions, was a plebiscite orator, and once wounded a German man by a shot, when the Orgesch-men planned to assassinate the local priest. He was sentenced for that to two years in prison, but was eventually pardoned because of an amnesty.

In spite of his German background, the blacksmith believes that nationality is something you assume in your mother's womb, and holds in contempt one of his relatives whose mind has been fluctuating in this respect depending on the wind. He cannot stand Germans, and calls them kłaks [as above]. He knows religion tells you to love all the people, but as to Germans, he "wouldn't help getting on bad with." Inside the forging shop, you can spot the inscription: "Boże, błogosław moją pracę" [God bless my labour]. The smith would not allow it to be painted over. And if any of the Germans had dared touch the inscription: "he would go the first, and me, follow him", the old man says, shaking his hammer menacingly. Outside the shop, visible is a signboard reading Schmiedemeister, blurry today. Before the war, they say, there was a Polish inscription, 'Master blacksmith', which was obliterated by the Germans. I have no idea how this Schmiedemeister has replaced it. It is doubtless that the signboard inscription was not an honorary matter for the smith, contrary to the apostrophe to God inside the forge.

His acquaintances say that when in the Nazi time someone entered the blacksmith's shop making the Nazi salute, he would spit and never accept commission in such cases. He would never utter the phrase Heil Hitler! himself, which was a matter of honour again. The Germans were aware of the smith's Polish patriotism, but left him alone owing to his old age. The blacksmith's son, for a change, was deported to the Oranienburg concentration camp.

${ }^{21}$ Franciszek Mehl [ed.]. 
During the war, the smith's forge played a momentous social role: it was there that the 'great Poloks' met to get reinvigorated; they repeated to one another the news broadcast by a foreign radio station. The blacksmith says he never had any doubt in the final victory over the Germans; not even when France was defeated. His son, having left the Oranienburg camp, sent him later during the war a rhymed prophecy on a broken cross, a hammer, and a great water - the prophecy that circulated in Warsaw at the time. The blacksmith also kept the prophecies of Fr. Marek [Jandołowicz], the Carmelite, on a splendid future for Poland. "And weep the children will: Oh mother, why hast thou Germanified us", the prophecy reputedly claimed. The blacksmith quoted it to a German chaplain after the Germans exited.

The most remarkable sophistication among the few people who, in my landlord's opinion, form the 'stem of Polishness' locally, is displayed by one of the farmers; let us codename him 'Biedronka' [Ladybird]. He used to be chairman of the local branch of the Association of Poles, and member of the Polish-German arbitration committee. He has toured Poland a great deal, and is familiar with Poznań, Cracow, or Warsaw. His daughter has had an opportunity to visit the places as distant as Lvov and Tarnopol. The plebiscite over, he considered moving to Poland, together with his son-in-law, one of those contributing to the 'stem of Polishness'. He was looking for a pen to buy in Poznań area and not far from Brześć [Brest]. But "it was apparently so destined" that he remain in Silesia and not elsewhere.

'Biedronka's' son-in-law, let us call him 'Górny', kept in his barn a secret depot of insurgent weapons and ammunition during the Silesian Uprisings. In the spring of 1939, he was displaced from Silesia by the Germans, and served nineteen weeks at a Środa prison after the war broke out. They had his jaw beaten during interrogations. When the war was on, he would never talk to his children in German, although the locals threatened that the Hitlerites were eavesdropping by the windows. His sons were part of the last brood of those attending the Polish school, together with Mr. 'Marczyk's' daughter. 'Górny's' daughter also completed her education with the Polish school in 'Giełczyn', and has most recently enrolled in an introductory course at the lyceum [secondary school] of pedagogy in Opole. She speaks Polish as if she were a Varsovian, whilst she claims she has learned it in 'Giełczyn', the credit going to the school and the books 
she has read. Admittedly, 'Biedronka' as well as 'Górny' talk to me using a language that is a transitory form between their vernacular and a literary register, a clear result of their former contacts with Poland. As 'Górny's' daughter says, she finds it so easy to switch from literary Polish to the dialect, or to German.

There are more such trilingual persons among the young generation: I have leastwise met two young female teachers from a local patriotic family, enjoying respect for a good hundred years now in 'Giełczyn', who can speak correct Polish. But this is not quite the case in point, since both young women were educated in Poland. The daughters of Mr. 'Marczyk', both graduates of the Polish school, can only speak the local patois and German.

What 'Marczyk' persistently stressed is that all the rather well-todo local farmers were 'great Poloks'; and conversely: most of the 'great Poloks' are fairly affluent farmers. Among them, only one let himself get caught up in the Hitlerite partai: a man who had considerable debts incurred, and could have lost his farmstead. Once he joined the partai, he was offered discounts and had his earnings facilitated.

The patriotic farmers form a distinct group, bonded by the ideology and honour of 'great Poles', and mostly linked through consanguinity or affinity. "The Great Poloks", 'Marczyk' says, "have been keeping themselves together, becoming related to one another". And indeed, he quoted to me, by names, the colligations linking eight or nine families. Some of these patriotic colligations reach outside 'Giełczyn'. 'Górny' is a brother-in-law of a 'colonel' that once led an insurgent troop from 'Giełczyn'. 'Marczyk' is related to a known patriotic family from the adjacent village; a few outstanding people have come from that family, among whom was a physician and Polish activist in Berlin who in August 1939, before St Roch's day, was killed there and his body thrown into the Spree. ${ }^{22}$ According to 'Marczyk', this marked the beginning of the war. (One of the streets in Opole bears the doctor's name today.) One of 'Marczyk's daughters was engaged to the son of a patriot from a village $10 \mathrm{~km}$ off 'Giełczyn', who was famous across the area. 'Górny' is related to this patriot's family. Some of the patriot farmers are close to each other also in terms of topography. The three adjacent pens at the hamlet where 'Marczyk' has his farmhouse were family home to six students of the Bytom gymnasium.

${ }^{22}$ The author probably refers to Augustyn Kośny (1896-1939) [ed.]. 
Similarly to Cieszyn Silesia, Polish national movement under the Prussian or Austrian rule had the class antagonism as its stimulant also in the Upper Silesian Basin: a Polish worker was subject to a German industrialist or landowner, German foremen or estate steward. National liberation trends were connected with the struggle for liberating the working class, socialist activists managed the national movement, whilst a Polish socialist newspaper was an organ of the patriots.

The rustic villages of the northern Opole Land after the division of Silesia showed a different picture, though. The Polish proletariat was too weak there to carry out an independent action. Growing a socialist or communist, the Polish worker or farmhand accepted the agenda of the German socialist or communist party, as long as either existed. A national ideology was cultivated there primarily by a group of economically independent people, related to professionals, whose influence penetrated into the village until the war, when most professionals and intellectuals of Opole region either left the country or were put in concentration camps. For this group, Polish patriotism did not have to do with class antagonism; even if one might trace certain class elements in this patriotism, this is only because the dignity of 'great Polok' added splendour to the landlordly class within the narrow milieu of the well-familiar people. The Polish patriotism of 'Giełczyn' was of a select nature.

But, did the 'great Polok' ideology in the post-plebiscite time not reach beyond the circle of wealthier farmers? 'Marczyk' admits that there were some good men among Polish petty farmers or farmhands. The name of one of the cottagers, a village head who was a "righteous and good Polok", was given to one of the 'Giełczyn' streets after the liberation. As I later found, however, this sottys owned more than four hectares of land, at any rate, whilst most of his fellow cottagers were small holders, their lands not exceeding two hectares. I made acquaintance with an old landless wild-bee keeper, one of those 'great Poles'. Apart from keeping his bees, this old man was in trade and dealt with machinery repairs; in his young years he worked for [Bronisław] Koraszewski in Opole, and his Polish patriotism was probably owed to this particular circumstance. The Polish school, 'Marczyk' says, was mainly supported by a handful of farmer families with a few kids each. The school register for the last years of the school's existence only features the names of quite well-off farmers. 
Yet, in the course of those dozen-or-so years, 'Marczyk' remarks, petty farmers or farmhands occasionally sent their children to the Polish school. There was a mechanic who keenly advocated the Polish school idea - to not much avail, though: as the man was childless himself, his efforts were often confronted with resistance: "Send your own kids to the Polish school!"

Based on what I have managed to learn during my stay in 'Giełczyn', one may infer that the individual cases of worker/farmhand patriots cannot challenge the fact that the 'great Polok' ideology was concentrated at the time within the group of farmers, one member of which was the master blacksmith who was wont to spit at the Nazi salute; his membership had resulted from colligations, acquaintances, and an independent position in his forge. Let me at this point, just in case, once again make the reservation that I rubbed shoulders mainly within the milieu of my landlords' acquaintances. Mr. Strzelecki, who visited the area thrice in 1945 and 1946, for a change, encountered people held to be great Poles almost exclusively among the farmers.

\section{VIII}

\section{A COMMUNITY OF 'FELLOW LOCALS'}

As an ideological stance, deliberate cult of certain values, based on a certitude of participating in a national community, a proactive stance calling for overcoming the scruples offered by the living conditions in the German period - a select stance, in a sense - Polishness appears to have been shared in the territory of our investigation by a scarce group whose part, perhaps a rather considerable one, is formed of would-be emigrants to Poland. After the division of Silesia, those latter ones entertained the idea to resettle into the Polish State but eventually failed to do so. This was due to economic reasons, or to the fact that their attachment to their native locality and the living conditions they were well acquainted with - in certain cases, also perhaps the sense of solidarity with their own group - prevailed over the attractiveness of Polish citizenship.

These people form a rather compact group, bound by the awareness of a shared ideology and common participation in a distant national community, once bound in organisational terms as well (Association of Poles, Polish school, Polish electoral committee, Polish agricultural organisations, etc.). In parallel, they belong to a community much 
larger than the group of 'great Poles', a much closer and more concrete one than the abstract national community; a community they are related to through the bonds of tradition and coexistence.

This is a wide community of local people whose Polishness is not ideological but moral and customs-related. To put it otherwise, it is a community where cultural elements of Polishness in life and in conduct are not tended to as an expression of their conviction about a communion with the Polish nation; instead, they are components of a local folklore, a familiar culture that makes this particular community distinct against the Germans. A sense of cultural singularity arousing against Germans, or even the awareness of being ethnically Polish, still does not imply inclusion in a Polish national community. The Poles were far away, behind the cordon - those Poles with respect to which the word 'Pole' had a nominal sense. If there occurred an opportunity to meet them, one's cultural separateness in contrast with them could be identified. This separateness appeared in an especially intense way with respect to comers from Poland in the first months after the war.

A seventy-year-old woman from a settlement located a few kilometres away of 'Giełczyn' thus worded her national position in the course of a conversation about the present-day relationships, on her way back from the vespers:

May we be Poloks; may we be Germanic; may we be Russkis; may we be Prusskis - if only we can labour, if only there's peace, if only there's things to eat, if only there's sugar for the kids.

This statement ought not to be seen as typical. In the first place, an old woman, excited by the talk about today's relationships, in which she has suffered severely from the 'Russes' and from 'Poloks', could not even think that such national indifferentism could make a bad impression on a stranger comer. No other dweller in that area would ever let himself or herself manifest such a practical stance, particularly in the period when Polishness was being verified. Next, the woman came from a settlement with mixed population - seemingly, mostly German-populated one - where there was no such national movement in the interwar period, based on what I know, of the sort that functioned in 'Giełczyn' all the same, owing its existence to a local group of 'great Poles'. This group exerted an impact on the surrounding 
environment. Something of this ideological Polishness radiated on those whom 'Marczyk' classed as a second, if not third, 'sort' of Poles. Such radiation did not probably reach the half-Germanised settlement in the woods which was home to that old woman.

However, therefore, the statement made by that woman is characteristic: it expresses an idea that, as it seems to me, is dominant outside of the circle of 'great Poloks' and which could be described as 'nominalism in national matters'. A real bond for such 'nominalists' is the one that links the 'fellow locals' - those from the local area of Silesia. What nationality category they are, depends on the political forces clashing one against the other somewhere above their heads, out of their control. After all, Hitler recognised all the Silesians as Germans during the war, save for those whom he deemed traitors of the German nation, and if he had won, one would have to come to terms with it. If acquaintance with the main stages of Silesian history had some impact on the ideological stance of the Upper Silesians, it was probably advantageous also to the said nominalism: after all, Silesia was once a Polish land, then it was Bohemian, then Austrian, for a long time; next, it came to Prussia and now is part of Poland again. "How's it going to be now: shall we be under the Russki, the Polok, or some sort of another, eh?", a woman from a hamlet right by the Oder River asked me bashfully.

\section{IX \\ TWO LANGUAGES}

As Silesia's political alliance with Poland in the past is a matter of the remotest Middle Ages, while its cultural connection with Poland proved very weak over the recent centuries (Polish publications spreading across Silesia before WWI were of Silesian origin, in a large majority), language has accordingly remained the main testimony of Upper Silesia's Polishness. Founded on the authority of Bohemian linguists, the linguistic criterion was the argument that was with good effect contrasted against the historical Bohemian or Czech claims laid from time to time to this country. Language was the factor which, in the awareness of Silesians, linked it with Polishness: in the course of the censuses before WWI, 1,200,000 Silesians quoted Polish as their native language. Even though a Silesian was not a member of the Association of Poles or vote the Polish list, he all the same realised 
he read a Polish newspaper and say prayers from a Polish prayer-book, and that the language of those Silesian prints is not much diverse from that of the language of books produced behind the cordon - the language of [Eliza] Orzeszkowa, [Henryk] Sienkiewicz, or [Bolesław] Prus, whose works in the interwar period were disseminated in Silesia in quite considerable numbers of copies.

But the Polish dialect was not the only language expressing the thoughts of Opole Land dwellers and serving as an instrument of communication in practical life. The generation whose women spoke no German whilst the men had barely a poor command of this language, the generation whose childhood years fell on the time before the Franco-Prussian War of 1870, has died out yet. For the culture of those living today characteristic was not only a dialect as such but, specifically, the colloquial regional Polish and the German language in varied proportion, depending on the circumstances and subject-matter discussed.

And the proportion varies by age: the old generation speaks a beautiful patois with refined archaisms, recalling at times a [Mikołaj] Rej or [Piotr] Skarga. German borrowings appear when official, technical, sometimes commercial, matters are tackled. But their command of written Polish is weaker: after all, these people went to school in the Kulturkampf period. [...]

In the young generation, apart from the 'great Polok' families, the amount of German words and phrases is steadily expanding. Even the daughters of 'great Poloks', when talking to each other, say that "the sugar in Opole costs hundert achtzig per two pounds", or, "time to aufstehen now". Small children do not speak Polish at all, save for those children of 'great Poles' that did not let themselves be intimidated by the wartime declarations that whoever spoke Polish was a traitor of the German nation. The proportion of German in the regional Polish dialect depends on the locality. The women on their way back from vespers to their forest settlement I have mentioned incessantly switch from the Polish dialect into German, their patois being stuffed with German phrases, much in the way sixteenth-century macaronicisms were stuffed with Latin. Nabend, Mahlzeit, "walk 'cross the wald", "pay sechs und zwanzig" can be heard amidst Polish words.

The increasing proportion of the German language in the local dialect is symptomatic to the growing role of German in the lives of these people; there have been more and more situations in which one 
had to use German: the military, offices, school, workplace and, during the war, the church and public places of all sorts. The sections of time during which one lived with and through the German language have expanded, whilst there were no social conditions favourable for severely separating these sections from private life and for living a double life, Polish and German. To some extent, such double life could be the case, to an extent, with those who held Polishness as a matter of ideology. For the others of the younger generation, language was, admittedly, a characteristic trait of group separateness; still, they differed from the Germans not in terms of no command of German but in that they used the dialect as well. The Polish dialect made them standing out not as a language used on a permanent basis but as a language one has learned at his or her home. The proportion of German was apparently not an important thing, since German was spoken in so many situations, and the 'fellow locals' used German phrases, to a larger or lesser extent, whenever they found it easier to do so.

This bilingualism is free of ideological connotations in equal measure as that of emigrants in France or in the United States, that is, in foreign-language environments, where during the day, by way of habit, one uses foreign expressions in their own home milieu, or even speaks one language and the other alternately, not even considering it to be some act of renouncement or desecration of the native, or family, speech. A Polish long-term émigré to France could, when talking to his wife, use French phrases without prejudice to his patriotism. Similarly, grown-up daughters of a 'great Pole' could use among themselves German phrases or expressions without harming their Polishness. This all the more concerns people who were no 'great Poles' but belonged to the Silesian community for whom Polish speech was one of the drivers of contracting the bond.

The foreign language spoken also by the familiar locals assumes, to an extent, characteristics of homeliness; particularly as an admixture. What disqualifies ideologically is complete replacement of the native language by the foreign one. Someone who does not understand a community's mother tongue ceases to be a fellow local. This is the reason why using a foreign language at home may become a deviation not because of the very fact of using the language but due to the effects it may have on children. And again, the situation of ethnically Polish people in Opole region reminds in this respect that of long-term émigrés in exile. Thus, these language-related relations 
ought not to be measured against the attitudes of people in the groups where the slogan to struggle against a foreign language was put forward; such was the case with the Congress Kingdom, where, for instance, women intellectuals pretended before the Russians that they did not understand their language and would be ready to use French instead, if need be. No-one put forward a like slogan in Silesia after the plebiscite, though. 'Great Poles' propagated the postulate of cultivating Polish speech, with nobody propagating its exclusiveness - be it for the reason that such a slogan would have been thoroughly unrealistic, given the conditions of the time and place.

There is, however, an area where the language actually used was of importance as far as Opole Land is concerned - not only for 'great Poles' but for the entire community of 'ethnic' Poles. Religion: sermons, confession, religious chants, is where Polish has held out the longest. German priests also learned their Polish, so they could use the language to fulfil their duties with it use. At the 'Giełczyn' church is an 1911 tombstone of its priest, K. Kittelmann, a German who read the Gospel in Polish, occasionally delivered Polish sermons and heard confessions in Polish; the tombstone features an appeal in Polish, below a German inscription: "Dear Parishioners, pray for your priest." As Polish was removed from the Church and singing in

Polish forbidden in the wartime years, the women from the Association of Christian Mothers began gathering in conspiracy in order to sing in Polish: not out of a love for Poland but out of the love to their religion and attachment to their songs, of which they could sing a great deal and to which they had been accustomed since their childhood years. The Polish language was an element of their Catholicism. It assumed a ritual character in that area - independently at all of the fact that Latin, rather than Polish, is the ritual language of the Catholic Church. The language switch in the relations with the supernatural world could influence the good result of the ritual ceremonies. Prayers said in another language might have not been heard, contrary to the prayers uttered in the forefathers' language. The faith of the forefathers was connected with their language. Stefan Czarnowski wrote on the association between religion and language, in his study on religious culture of Polish rural people:

Albeit [Polish countryman] knows that there are other Catholic nations, he considers them orthodox not to the degree of his own; in any case, 
less tightly are they joined with the Church. He considers them situating themselves closer to the peripheries of the Catholic community, more remote from God and the Lord's Saints, whose native language is Polish, as he believes it to be. ${ }^{23}$

Hence, the grim combats fought by the Poles with the Irish clergy in the United States of America. ${ }^{24}$

The Germans realised that it was owing to these ritual attitudes that the Church was a mainstay of the Polish language in Silesia. They tried to overcome this using more subtle measures, before they eventually resorted to brutal coercion. Before the war, as I heard from a 'Giełczyn' local, the villages were toured by automobiles which announced that old prayer books were to be exchanged, free of charge, into new, prettily bound ones. The people did not initially realise that the exchange of worn-and-torn books for their new counterparts was essentially an exchange of Polish books into German books, which was due to imply conversing with God in German. ${ }^{25}$

This ritual character of the language appears to a much lesser degree in cemetery inscriptions. Albeit the gradual fadeout of Polish inscriptions on tombstones in the Nazi time ensued, no doubt, from a political pressure. Verba volant, scripta manent: not to say, words engraved on a stone. The inscription was a document that could disgrace somebody even years afterwards. Yet, German inscriptions on tombstones owned by Polish families are also reported for before 1933, a time when there was no such pressure with regards to cemeteries. My question, what was the background of those German inscriptions on Polish tombstones at that very time, was responded thus: some were of the opinion that a German tombstone was more 'first-rate'. This same factor, after all, attenuated the resistance with respect to German prayer books: although they were not in agreement with the tradition, they were more elegant, in any case. There is a new incentive behind the conduct that we are coming across; there will be an opportunity to refer back to this thread.

${ }^{23}$ Stefan Czarnowski, 'Kultura religijna wiejskiego ludu polskiego', in idem, Kultura, ed. Ludwik Krzywicki (2nd edn., Bydgoszcz, 1946), 126.

${ }^{24}$ Ibidem.

${ }^{25}$ Other practices aimed at depriving Polish people of their prayer books are covered by the (aforementioned) Memorial of the Association of Poles in Germany of 2nd June 1938. 
It is worth noting that among the tombstones from the years 1937-9, the time fear of the Nazis had grown very strong, one repeatedly comes across tombstones with no word or phrase but the Christian name and surname. In lieu of a 'born' word, there is an asterisk beside the date, which is given in numbers only; instead of 'died', there is a small cross. The tomb features no religious inscription. Those scarce tacit tombstones are a completely different story: avoiding German owing not to religious (wordless tombstone also diverts from a traditional pattern) but patriotic reasons. These are, namely, tombs of families of the 'great Poles' who did not want their brothers, sisters, or fathers being considered, ever, as Germans.

\section{$\mathrm{X}$ \\ THE FAITH OF THE FOREFATHERS}

The significance the faithful attribute to their language preserved in the realm of religion is rooted, as we have seen, in a ritual tinge of any act or function connected with religious cult, especially, in the magical role of word: a role that depends on the form of the word no lesser than from its content. Therefore, the modified spelling of the name 'Jesus' was the direct impulse for the seventeenth-century schism in the Orthodox Church - and, as demonstrated in practice by the Union of Brest, the alteration of the dogmas was an easier thing to realise among the masses than the shift to another language of service.

Yet, beside the care about the efficiency of religious practices, there is still another thing concerned. Catholicism, a universalist religion, is nationalised, or regionalised, by the local language, which in this respect performs a function similar to that of national or regional patron saints. As Czarnowski wrote in the study quoted a moment ago, the Polish peasant believed that:

When a Catholic, a German is not a genuine German; it is a daitschCatholic [i.e. 'Deutsch-Catholic']: some very uncanny transitory formation, a Catholic like a Pole, speaking the language of the 'Luthers'; a pitiable being, as a matter of fact, one that has something missing to be a Catholic in the full meaning of the word. ${ }^{26}$

${ }^{26}$ Czarnowski, 'Kultura religijna', 126-7. 
Such was the case, for instance, in Masovia, where I came across the name of the said transitory piece of work in a more deformed, and thus more mysterious, form: dintch-Catholic. In Silesia, where Catholic Germans were no rarity and, more importantly, a Polish parish could have a German priest assiduously winning trust from his parishioners - like the Rev. Kittelmann himself - and, where German Catholics running for the Parliament won a really considerable share of vote, a German Catholic could not be regarded as some not-quite-real German and not-quite-genuine a Catholic, perhaps of a worse sort; still, even there could he be perceived as a different kind of Catholic - one that says his prayers in a different way, using dissimilar words, even though their content might be the same.

With Polish speech in the sermons, chants, prayers and confessions, Catholicism constitutes the religion peculiar to the community whose members the autochthonous people of Opole Land perceived themselves to be. This religion, the one 'of their own', formed a powerful socially binding factor. But apart from the circle of the 'great Poles', who saw in Catholicism a link to the Polish nation, it was not a factor of national bond but rather, of a regional bond, whereas Lutheranism was in that milieu a stigma of Germanness: in 'Giełczyn', I have come across the word ewangelik (i.e. Protestant/ Lutheran) used euphemistically instead of 'German' (in the expression "An ewangelik, but a good man still").

'Great Poloks' know that Poland is a Catholic country; that their Catholicism is a heritage from their ancestors who opposed the Germans ("once the Piasts got Luthered in Silesia, the country went Germanic too"); but also for them is Catholicism a familiar and regional religion. The cult of Our Lady of Częstochowa is part of this regional Catholicism. The church fairs in Częstochowa, frequented in the interwar years by military companies from 'Giełczyn', holding group passports - with solemn rituals attended together with thousands of Polish peasants from behind the cordon, with whom one could communicate using the familiar local tongue - doubtlessly gave an opportunity for arousal or reinforcement of national awareness. But this connecting-link role was challenged by companies marching to the fairs in the German localities of Wartha (former [and today's] Bardo) and Albendorf [Wambierzyce] in Kłodzko Silesia, where festive ceremonies were attended together with German Catholics, with whom a substantial majority of 'Giełczyn' dwellers could 
communicate to no worse effect than with Polish rural populace gathered in Częstochowa.

These same people would go to Częstochowa one year and then, the following year, to Albendorf. It sometimes happened that on the same Our Lady feast, the husband would go to Albendorf while his wife was visiting Częstochowa. One of the greatest Polish patriots in 'Giełczyn' - one of those who, in the words of my landlord, constituted a 'stem of Polishness' there - many a time led the companies to Albendorf, received in a very kindly spirit by the local Catholic Germans. As he told me, he had come across reproaches that he was leading his companies to purely German localities, but he responded then, "Why, may those Germans from Albendorf come to the conviction that Poles live near Opole as well!"

This was obviously an instance of rationalisation, counteracting these objections: the substantive incentive stemmed from the regional tradition. Along with Mount St Anne near Opole, the local religion's topography extended to the foreign hub of Częstochowa as well as Wartha and Albendorf, also situated outside the limits of Upper Silesia. It was the connection between Częstochowa and Albendorf that determined the peculiarity of the local religion: the cult of the Black Madonna of Częstochowa made the difference between the local Silesians and the German Catholics. The tradition of sacred sites in Kłodzko Silesia made them different from the Polish teams they were meeting in Częstochowa. For the aforementioned patriot, Częstochowa had two functions: it was a sacred place of Polish national community, the seat of the Queen of the Polish Crown, and a sacred venue for the regional community; this latter function was shared with Mount St Anne and Albendorf.

The fact that religion was a medium of the regional bond in Opole Silesia was reflected in the Silesians' attitude toward the clergy. Even for the 'great Poles' whom I talked to of these matters, the patriot priests who have imprinted themselves in the history of Polish national movement in Silesia are patriot and priests at the same time: a priest, like a blacksmith, for that matter, can be a patriot, cannot he. A priest is even more disposed to be one, due to his education; however, nobody would expect a priest to be a patriot just because he happens to be a priest.

Quite the opposite: I have a few times come across the statement whereby priests, in their capacity as such, ought care about the 
matters of the Church, rather than politics. The figure of a certain $\mathrm{K}^{27}$ enjoys great respect from the locals: during the plebiscite, the Orgeschmen attempted to murder this priest; he had his rectory doorknobs smeared with manure. Another one, named P., ${ }^{28}$ has earned his respect also: whilst keeping away from politics and not interfering with the national movement, he has a new church reared to his credit.

No-one is scandalised by his recommendations to vote the Centre or the Polish ticket in the election, for either of the electoral rolls was Catholic, and thus worth supporting from his priestly standpoint. It would be wrong for him if, while recommending the Centre, he would have banned to vote the Polish ticket, for in such a case he would have appeared as a politician; worse even, a politician inimical to Polishness. As my landlord's son told me, the Rev. P. "was not a rightful Pole, or a rightful German; he was an Upper-Silesian". ${ }^{29}$ But as to matters ecclesial, he was uncompromising, and he even might have been deported by the Germans in the war years, had he not died. In the Nazi time, he was courageous enough to say from the pulpit, "God the Lord died on the Cross and not on a Hakenkreuz". In the opinion of his Polish parishioners, P. was just as a priest should be.

"Religion should be equal, superior to nationalities", 'Marczyk' once told me, condemning a nationalistic stance of a German priest from the adjacent parish, who during WWI forbade his parishioners to frequent St Roch's church, ${ }^{30}$ since its patron was a Frenchman. That priest was soon after struck by a thunder on his way, the landlord says, letting me guess that Saint Roch took his revenge on him. Of course, the abstract statement whereby religion ought to be superior to nationalities stands in no collision with one's attachment to an entire complex of local religious traditions and local rituals.

The present chaplain can speak Polish, it's just that he wouldn't like to, 'Marczyk' concludes. Today's priest, ${ }^{31}$ bearing a Polish

27 The Rev. Mikołaj Knosała, the priest of St Catherine's Parish in 1911-21 [ed.].

${ }^{28}$ The Rev. Franciszek Poziemba; the new edifice of St Catherine's church was erected in 1933-4 [ed.].

${ }^{29}$ The farmer uses the word prawy, which nowadays stands for 'righteous', following the Old-Polish meaning of 'true' (prawdziwy).

30 Situated at the Dobrzeń cemetery, it is a pilgrimage church, with a long indulgence fete tradition (St Roch's fete) [ed.].

${ }^{31}$ At the time Ossowski stayed at Dobrzeń Wielki, the Rev. Hubert Nieborowski was the parochial priest and the Rev. Karl Schaffner was the vicar [ed.]. 
name, also does not want to read out the Gospel in Polish, or say Polish sermons, though he can speak Polish. Since the moment the Polish authorities seized Opole Land, he only happened to read a Polish Gospel once. The Gospel in Polish and Polish sermons were, after all, part of the local religious tradition which even the German priests respected, until Hitler barred the practice. Hence, 'Marczyk' is not going to regret if both local priests are displaced some day by the authorities, although it is otherwise very bad for a parish to remain priestless. Well, he still hopes that there will be some priests from Poland available for 'Giełczyn'.

Regardless of his personal political views, a priest ought to respect the local religious tradition, on account of his duties. When Hitler ordered that Polish inscriptions be removed from the church, the blacksmith and the sacristan asked N., the then-priest, ${ }^{32}$ to let the Polish inscriptions featured below the church's Stations of the Cross be covered with paper and not painted over. The priest refused, which the blacksmith has severely held against him - and this for religious rather than national reasons, for it was a known fact anyway that the Rev. N., bearer of a Polish noble surname, did not feel a Polish identity to be his own.

To arrive at a profile of the social group concerned, and to find what shape the notion of apostasy takes within that group, and who is namely deemed a renegade, is a matter of importance.

For the residents of 'Giełczyn', membership in a national community is gradable. We have said that the word 'Pole' is adjectival when used with respect to the local people: one can be a Pole to a larger or smaller extent - this being not just a matter of one's internal feeling; as we have seen, the official censuses carried out in interwar Prussia produced no clear delimitation between the categories of Germans and Poles. Affiliation with a group of the faithful is clearly determined, for a change: either you are a Catholic, or you are not. There are the 'bilinguals', but no 'bi-religious'. This being the case, it is not surprising that the notion of apostasy primarily has to do with religion. A religious apostate is the clearest instance of a renegade amongst fellow locals.

"Of the dissenters from the faith, there were some twenty in ‘Giełczyn'”, my landlord remarked. "Did they turn Protestant?”, asked I.

32 The Rev. Hubert Nieborowski was the priest in 1939-46 [ed.]. 
"Not Protestant, no: they switched to the Hitlerite faith." As one of them explained,

as is the case with any piece of machinery, which gets worn down with time, same is true for the faith. The Catholic faith is quite ancient, and has got worn out. Hitler wants to rectify it.

I heard this parallel several times when in 'Giełczyn'. As I was told, when an apostate was explaining it at the forge, the smith shouted, indignant: "So you're going to improve God Himself?!" I asked whether that apostate went to church at all. Well he did, but just to 'do the watching' [dial., wachtowac'], as they put it there. The dissenters claimed their renegade status through the court. They had their 'doers' [sprawcy], as my landlord names them (referring to curators acting in lieu of the priests). In case anyone of them died, the funeral would not be attended by a priest.

Change of surname was something like dissent - not from a faith, to be sure, but from the family tradition. Seeking their career opportunities, some residents of Opole Land replaced their Polish names into German ones. Thus, a certain Wicha "convertyed ist to a Wichman", albeit his wife had descended from the 'great Poloks'. Convertyed ist he, because he worked at the szosei [dial., road] and had to have his name altered in order to keep his post. Two sons of 'Gwiozda', the old man, a 'great Polok' who actively partook in the plebiscite action, renamed themselves Stern, for the Germans had been "terrybly teassing them because of their father; they called them by 'Polnische Agitator', 'Korfanty', 33 or 'Grosse Pole'”.

Although changed name did not arouse an indignation similar to that implied by altered faith, such decision was, in the main, judged in negative terms. Yet, the rule of familiarity tended to prevail over Polishness in such cases. When someone had his name transferred, the blacksmith says, it is as if he has trampled his forefathers' name.

33 Wojciech Korfanty (1873-1939) was the most eminent Upper-Silesian politician, member of the Reichstag (1903-12, 1918), Polish plebiscite commissioner and Dictator of the Third Silesian Uprising; later on, member of the Parliament of the 2nd Republic of Poland, a senator, deputy to the Silesian Sejm (province parliament); emigrated politically to Czechoslovakia and France in 1935-9, back in his home country since April 1939. He died after serving a few months in detention, right before WWII broke out [ed.]. 
It is with recognition that he tells a story about a German named Wojciechowski, a postmaster from Opole, who in spite of the pressure from the Nazis did not agree to have his surname changed, precisely in commemoration of his father. The smith who is telling me the story would not have his German surname [Mehl] changed to a Polish one, albeit he is a 'great Polok' and has an aversion toward Germans.

The religious traditionalism of Opole Silesians, quite likely more considerable than in other provinces of Poland, is connected with moral and customs-related conservatism of their daily life, which stands in severe contrast with the region's economy based on technologies using appliances far more advanced than those used in Masovia or Lesser Poland, and with the rationality of the management system. The expression "This is not how our fathers taught us to do" is equal to moral rebuke. "It is said in the Holy Scripture", one of the aged farmers says, "that at the Last Judgment, the adulterer shall hide behind the robber."

One of the symptoms of the conservatism of morals and customs are local nicknames attached to most of the well-settled inhabitants, probably all the farmers among them. These nicknames are often attached to cottages: whoever purchases or inherits a cottage, takes over the nickname together with it; sometimes, it can be the name of the former owner, or the proprietor from a few generations before. Rather than saying "going to Warzęcha", they would say "going to Korol", since Warzęcha's father has bought a cottage from a certain Korol and thus the latter's name has adhered to the Warzęchas. A girl who knows the Warzęcha family well could not reply to the question where Warzęcha lives. Our landlord is referred to as 'Kowol' [dial., Blacksmith], as his starzyk [dial., grandfather], who had bought the farmstead, was a smith. "There's no kunst ['craft'] in being a kowol as an acqueerred job; the kunst is to be born a kowol", as my landlord puts it jokingly. One of the neighbours is commonly known as 'Golembus', his actual surname not being in use in the neighbourly relations. Several dozen years ago, perhaps even a hundred, the starzyk of this 'Golembus', sailing along the Oder River, thrust his barge onto a shallow and long could not pull it off out of it. His neighbours said, "Well, well, he's come across America, like Golembus [Columbus]!" ever since then, it is the third generation now that bear the nickname 'Golembus'. One of the previous sottyses was nicknamed 'Gnida'; since the word is abusive [meaning 'nit' or 'louse'], he would not let the others address him so at communal gatherings. 
As I was told in 'Giełczyn', apart from local nicknames there exist in the individual villages certain local traits of the language, local vocabularies, thus also testifying to a persistence of cultural patterns in that milieu. They say chustka ['kerchief', in standard Polish] in 'Giełczyn', whilst in an adjacent locality would name it sadka; daddy and mummy are called tatulek, matulka in the former and tacicek, matuchna in the latter; similarly, there is klaca [dial. for 'mare'] or, elsewhere, kobyta [standard Polish for 'mare']. I have had no opportunity to check for these differences in the neighbouring village $(3 \mathrm{~km}$ away), but they function in the 'Giełczyn' people's awareness.

\section{XI \\ WARTIME OPPRESSION AND THE BURDEN OF LIBERATION}

Hitler's coming to power and, in particular, the Nazi regime during the war years have caused pretty deep a transformation in the social relations of rural communities and their residents' attitudes. The Nazis changed their policy with respect to regional groups once the war was on: a sharp division was applied with the local population into Poles and Germans, with nothing else coming in between these two exclusive categories.

Until now, we have been telling you - the Upper Silesian people were told in September 1939 - that the Upper-Silesian dialect was a Wasserpolnisch, rather than a dialect of Polish. That was untrue. We were saying this for propagandist reasons. Now, what we are stating is that the Upper-Silesian dialect is the Polish language. Whoever uses it, he or she is a Pole, and they shall be dealt with as such. ${ }^{34}$

Boards with inscriptions claiming, "Wer polnisch spricht ist Deutschlands Verräter" appeared in 'Giełczyn' at that time. ${ }^{35}$

The Nazi terror entailed exacerbated internal antagonisms within the village. The servants of the regime, who in spite of their family and neighbourly relations were placed outside of their local community and became members of an alien collectivity which did not tolerate obligations or duties with respect to other such clusters, formed one

${ }^{34}$ The content of this speech has been quoted to me by the Secretary to the Commune of 'Giełczyn', from his memory; he has heard the speech in Pszczyna region.

35 "Whoever speaks Polish is a traitor of Germany" [the fatherland] [ed.]. 
extreme. Not all of those who became members of 'Hitler's partai' during the war grew strangers to their local community: as we know, some would join the party just in order to hold down their jobs or get promoted, others, those more apprehensive, could not resist the pressure. Not a few partai-men provided their services to their endangered neighbours, as I have already mentioned. This observation has been confirmed by a young man from the vicinity of Częstochowa, who during the war was brought by the Germans to 'Giełczyn' to do forced labour there; he has remained in the village as a local militiaman [i.e. policeman] now. But those "who chazed after Hitler", as one of the farmers put it - mostly, young men to be bewared of, those who removed the icons of Our Lady of Częstochowa, and officially claimed their apostasy from the Church - were breaching their local community's ties and moved to another cultural circle, to the extent they could because of their former habits. "A German who waz a good man is better than an informant Polok", 'Marczyk' concludes.

At the other extreme were the people who were sent to concentration camps or who remained in hiding seeking refuge from such a lot; also, those who were ready for a certain risk in order to preserve their dignity and to stay loyal to certain values they cherished. Those would never put up a Nazi flag, remove Polish inscriptions within their pens, or raise their hands the way the Nazis did; they would always speak Polish at their homes, just as they did before, and taught their little children the Polish speech. Somewhat more complicated is the picture of those who listened to English radio broadcasts, as in their case, beside their enmity toward the regime, it was curiosity that pushed them to perform illegal deeds. In any case, committing a political crime, be it for the sake of curiosity alone, no doubt implied serious social consequences in a milieu accustomed to living a legal life: those listening to the radio, of whom there were reportedly a lot, were getting tied to the conspiratorial world and to the Poles deported to Silesia as coerced labourers. ${ }^{36}$

Spread between these two extremes, the rural community, in vast majority, was exposed to the influences from both. Their aversion to the Nazi government for its downright suppression of the religious traditions, for the new people bossing around, for the dread and sense

${ }^{36}$ The said militiaman from near Częstochowa also used to visit one of the local farmers to listen to the English radio. 
of uncertainty aroused by the party and government authorities - and, on the other hand, the opportunism dictating that they should adapt themselves to the new conditions, and the bewitchment with the Nazis' unparalleled victories in the first two years of the war: all these incentives were repeatedly pushing the rural community in one direction or the other.

The campaign against the Black Madonna has given birth to a legend. The story is told among the villagers about a local teacher - a ktak and devurrer ['devourer'] of the Poloks - who in 1942, together with two dissenters, intended to tear off the icon of Our Lady of Częstochowa from the trunk of a pine by which a miracle had once occurred. All three men fell down as if they were dead, and the others had to carry them away to a nearby Deutschemädelhaus. One of those personal enemies of Our Lady, a forester, has grown stupid ever since, never coming around again.

The villagers were not too well disposed toward Jews, who were very scarce in the area anyway. As one of the 'great Poloks' explained, Jews in Silesia had always supported Germans against Poles, and during the plebiscite paid big money for pro-German canvassing; with Hitler in power, they raised their hand, saluting one another with the phrase Heil Hitler! There were such who claimed that the Jews had deserved their fortune as those who were lackeying to the Germans. Yet, the way the Nazis dealt with the Jews aroused disapproval, as the sense of law-and-order, deep-rooted among Silesians, was striking and shocking. "It was not fair", one landlord told me, "that, with half the property confiscated from a Jew, he was ordered to pay a tax upon the whole." This is quite characteristic a statement, especially that the farmer knew what happened to the Jewry later on. (Let me digress by finding that Jews are generally perceived there as people of a different faith rather than race. Baptised Jews were protected from prosecution during the war, and today they are spoken of with good will.) The Nazi salute also collided with the customs and morals: "None of the emperors ordained that such a salute be made, as that man did, who was without some considerable education", one of the brighter-minded landlords told me. When any of the young men entered the cottage saying Heil Hitler!, 'Marczyk's' wife would ask him, "So this is what you've been taught by your fathers?".

The exclusion of their small children from the current of language tradition, that is, deprivation of their mother tongue, was an important 
turn in the family lives of most of the villagers. The head of a local Polish school, set up in 1945, claims, perhaps a little exaggeratingly, that of more than five hundred children, those of just a few patriots could speak good Polish (Silesian dialect). When in the German school during the war, these children entered Nazi organisations at a very early stage, to counteract the influence of which was dangerous; hence, this new generation was educated to a new culture and ideology. The Hitlerite severities menaced the Polishness and, to no lesser extent, the traditional customs and morality, and coherence, of the Silesian community.

As the war unfolded, the sense of stability was declining, while the awareness was emerging of the possible changes, going one way or the other, depending on the war developments. Plebiscite sentiments began reoccurring, in this respect. Germany's defeat at Stalingrad implied an intensified atmosphere of this kind. The possibility of the final decline of Germany, with the frontier of Poland shifted behind Opole, was advantageous to the spread of the patriotic movement. Listening to foreign radio broadcasts and orally sharing the pieces of news heard on the radio was also favourable in this context.

'Marczyk's' sister-in-law explained the NSDAP acronym as the announcement: "Now, Sylesians Drive in Amidst your Pippel!" [orig., dial., nasi zaś do wos przyńda!]. Later on, prophecies of a revival of Poland were repeated over and over; numerous anti-Nazi anecdotes started circulating, some of them imported from Berlin. The people were glad when told about a German clerk who, on inspecting the slaughter of swine, once entered the cottage, saying, "Heil Hitler, wo hängt das Schwein?". ${ }^{37}$ They were glad to hear the Führer could be thought of as a swine, and that one could at all figure out the Führer, the formidable Führer himself, hanged. In late 1944, the villagers mostly awaited a liberation.

And then the liberation came. Yet, the shape it assumed was one of a disaster. Apart from the few individuals who were taken to a camp or forced to flee, and the families who had lost a relative on the warfront, it was not until December 1944 that 'Giełczyn' locals began suffering the war keenly. The life in the village went on calmly, the coupon rations satisfactory, and the economic conditions pretty bearable. When talking to some of the village's locals, particularly

37 "Heil Hitler, and where's the hog hanged?". 
female ones, I have noticed that when talking about the pre-war time, what they mean is the period before December 1944.

It was then that the war came upon them, sweeping the calm old time away. The frontline moved forth in December, followed by an invasion of conflagrations, requisitions, robberies, young women getting raped. There were few girls in the village who, the locals say, have not been ruffled through and dumbstrucken, with their parents often having to watch it. The fear of marauders had not gone by the time I stayed in 'Giełczyn', which was in August 1945. The cannonades abated, the first wave of 'Poloks' came over; but these Poles did not bring Silesia any closer to Poland. For the 'Giełczyn' community, this marked a further stage of wartime calamities. Swift-legged looters began plaguing around: all the more ominous they were that they shielded themselves against the scared populace with their official function. Apart from the lust for trophies, some comers from the Dąbrowa Górnicza Basin were propelled by the eagerness to take revenge on the Silesians for the wrongs suffered during the occupation from the German gendarmes of a Silesian origin, who spoke a Silesian patois. It was not much difficult to demonstrate to a Silesian that he was a German, and draw the consequences, in case his seven- or eight-year-old child could speak no Polish.

In the spring of 1945, 'Giełczyn' was terrorised for three months by the Commune's head officer, who, as they said, had once arrived with one jacket and escaped from 'Giełczyn' in the night with three waggons. As may be inferred from the concordant accounts of the villagers, the man was talented and brave (he approached armed marauders with a revolver, which quite impressed the local folks), and had a gift for organising things; but, at the same time, the image he left of himself among the locals shows him as a man of bandit inclinations, the one who displaced the wealthier farmers as alleged Germans, in order to pillage their houses. This wiktać [dial., 'jokester'] and miglanc [dial., 'sharpie'/'lazybones'] spoke of himself as a People's Army officer, Home Army officer, or Master of Philosophy, depending on the purpose.

And he was so good in keeping his villagers intimidated that when 'Marczyk' wrote a complaint against him some day to the Polish authorities, he could find nobody in the village who would dare sign it; everyone quailed that they could be displaced for it by the accused. Finally, 'Marczyk' himself signed the complaint, "for he 
has no fear when there's something to be done for the sake of justice and honour". 38

To the embarrassment and sadness of the 'great Poles', it was individuals of such sort that the Polish nation offered itself to 'Giełczyn' in the first days after the liberation. This opinion was not improved by the settlers from Lvov who came to 'Giełczyn' and its adjacent villages in the late spring or early summer of 1945 . There were not many of them settling down in 'Giełczyn' itself, for there were scarce German farmsteads; more of them arrived in the adjacent villages. The clash between these two communities with different cultures, customs and morals, and economic system would have to be tackled by a separate study. For the assiduous, thrifty and systematic Silesian people, those repatriated persons who had not yet managed to adapt to the new conditions, accustomed instead to a not-too-intense husbandry on excellent soils, embittered because they had to desert their pens and homeland, not yet quitting the idea to return home, were aliens who did not quite understand the Silesians. Rather than that, they demoralised them with their laziness and unreliableness, caused or heightened by the wartime ordeals and emigration.

Here are some characteristic stories indicating what a repatriate looked like in the first months after his or her arrival in Silesia, as seen by the locals:

The son of a farmer, graduate of the Bytom gymnasium - They are not willing to work here. They had an excellent land in their place; just scratch it with a wooden plough, and you've got a real rye growing up! In Silesia, you wouldn't leave but the smallest patch of land. You don't pasture your cattle in the field in the summer, just cut the foods for it, and board at the cowshed. Those do graze their cattle in the field. This year, the poorer people from the countryside, having no livestock, used their grubbing-hoes to dig up their two morgues [of land], leaving not a piece for him. We know how to work, and want to work; just want them to leave us alone. An old woman from the adjacent village - A Silesian works, he eats not,

${ }^{38}$ As I have recently learned, this wójt was sued in an Opole court in 1946 for what he had perpetrated in 'Giełczyn', and eventually sentenced to sixteen years in prison. This made a good impression on 'Giełczyn' residents, although pessimists were saying that a man of this type was able to wriggle out of gaol as well. Characteristically, one of the 'great Poles', on making his testimony, expressed his view that the Germans had not done as much harm to the Polish cause in 'Giełczyn' over a hundred years as that communal head did within three months of his rule. 
and saves for [orig., dial., sparuje] his kids. The people from the other parts don't want to work.

A farmer from a Frederician colony, where, in lieu of displaced Germans, sixty-seven repatriated families from behind Lvov, alongside twenty native families, were placed - You didn't know what a padlock was in the earlier days, for they were unneeded. Today, repatriates are not willing to work themselves, whilst they do not respect the others' property. They're just standing, doing nothing. The horses are grazing when there's work to do, and our people have no horses. Even though they might be going away from here, or count that they'll be back with their places, they should not, after all, be watching the land turning into fallow, overgrown with couch-grass. Land ought not to be left uncultivated.

- The Germans miscalled us 'Poloks', those miscall us Germans. And they themselves are not 'real Poloks': they talk, somehow, in Ukrainian or in Russki. A farmer from 'Giełczyn' - Two repatriated persons have arrived in 'Giełczyn', they sayed they're not going to plant such pebbles. And what's that, pebbles or not, the land must needs be cultivated.

An old man from the adjacent village - Those repatriates is nought folks. Gnojecs ['lazybones']. Fit for nought for work. He goes on a cart, and there's someone asking he be picked up, and he shan't do. Me, if I were to live with people of the sort, then I'd rather live somewhere on the shelters [i.e. be sheltered under someone's roof].

In line with the sociological law that can be described as "the law of the background', living beside the repatriates has weakened among the Silesians the sense of social distance against Germans, and caused the Germans, when reminisced, began appearing as people of the same culture, closer and more familiar than those 'Poloks' speaking a Ukrainian-accented Polish and naming Silesians 'Germans'. Only the group of 'great Poloks' kept up the recollection of Polish-German antagonism, endeavouring to oppose the effect of 'the law of the background'.

The sermon delivered under the open sky by a visiting Silesian priest, at the church cemetery, as part of a great church fete that took place during my stay in 'Giełczyn', attracting throngs of people from the area, was imbued with a Jeremiah mode: the words sounded as if they were uttered in the days of defeat, rather than liberation. The chorus reappeared, "There is a load of sins weighing heavy on the nations, if such atrocities and inhumanities have occurred." It was clear that the priest was talking about the misfortunes affecting the local population in the last few months. 
The repatriates from Lvov considered the sermon delivered in Polish for the Germans. The local people, including local Polish patriots - save for a young female teacher who knew about the torments Poles had been through during the German occupation - did not see anything inappropriate about the sermon. For one thing, they were used to the fact that the pulpit was not a place for the national sentiments to radiate from, whereas the preacher's words did harmonise with the frame-of-mind their shared at the time, imbued with disillusionment, grievance, and uncertainty. It was perhaps because of this atmosphere that the song Serdeczna Matko (Beloved Mother), barred once, it is rumoured, under Kaiser Wilhelm, was not sung at that ceremony.

XII

\section{REGIONAL BOND AGAINST BROADER COMMUNITIES}

Let us now remind the phrase "he was not a rightful Pole, or a rightful German; he was an Upper-Silesian": thus my landlord's son described a local priest who died in the war years, one who did not take fright of the Nazis and who was treated by the young man and his fellow villagers with complete respect.

In the light of the materials gathered, we realise that the quoted description is extendable to a substantial majority of residents of 'Giełczyn' and its surrounding villages. Their self-awareness is primarily that of Upper-Silesians; more importantly, Upper-Silesians they are for good, and by birth. This is the predestined bond, a virtually indissoluble one, which we have been used to perceive as an attribute of participation in a national community. Apart from a scarce group of those professing a national ideology, who have assimilated their nationalist attitude to the patriots from behind the former cordon, nationality is approached as something incomparably less persistent something of the sort of membership with a political party, something that is less tightly connected with man than his faith and may be conditional upon some political forces clashing against one another somewhere above human heads.

When once in Bukowina [Tatrzańska] in Podhale, I was told a story about an old gazda [dial., 'farmer/sheep-breeder'] who was persuaded at the registration office during the German occupation to declare himself a 'Mountaineer' as far as 'Ethnicity'. "A mountaineer, that's 
what I have alwyz been", the man replied, "but under Austria, registered they had me as an 'Austrian', under Poland, as a 'Pole'; now that there's a Gouvernement here, you can enter me a 'Governor'”. For that gazda of Bukowina, this was in all probability a witty dodge, but this excuse reminds one of the statement made by a gazda from Cieszyn Silesia, which was no doubt sincere and would reflect the stance dominant among the 'Giełczyn' populace: a nationality may change, but the Upper-Silesian identity will be there, always.

Participation in a regional community is decisive, primarily, as far as the division into our and alien people is concerned. True, during the Uprising some Upper-Silesians joined the German troops and fought alongside the Germans against the other Upper-Silesians who had joined the Polish troops, for a change. But the Uprising is also reminisced with its fratricidal struggles incited by aliens. There were Upper-Silesians who fought for all their own folks to become Polish; and there were such who combated for all their own ones to remain with the Germans. The fierce hatred that kindled the opponents is a phenomenon common to fratricidal, or domestic, conflicts.

As the leader of the insurgents from 'Giełczyn' says, during WWI there was no difference between those to become the Orgesh-men and the insurgents-to-be; the former did not appear to be greater friends of the Germans. During the plebiscite, the incentive for their pro-German orientation was, mostly, of economic nature. CounterPolish organisations were primarily joined by workers going away, in large teams, to do seasonal labour in Saxony, Hannover, or Westphalia. They could make a good money there; incorporation of Silesia to Poland would deprive them of this earning opportunity, they expected.

In Upper Silesia, the regional bond, similarly to religious affiliation, has several centuries of tradition behind it. The issue of national affiliation is of recent date. The elderly can remember the moment the interest aroused in this matter. The sense of unity between the immemorial regional community and a broader, national or ethnic community, occurred there in wider or narrower circles, more or less intensively, informed by a variety of circumstances: be it the struggle for the language and own parliamentary deputies in reply to the Bismarckian Kulturkampf, which endangered not only the Polish identity but also the 'homeliness' of Upper Silesia; or, the plebiscite-related combats; or, the reaction to the ruthlessness of the Nazi rule after the Stalingrad defeat. 
I have no data enabling me to realise in what ways the regional bond intersected with the ideological bond of a class background, in the groups of socialists and communists linking Silesians and Germans together. One may suspect, though, that among the numerous votes cast in the pre-Nazi time in 'Giełczyn' for the socialist and communist tickets, some must have resulted from the conviction that socialism or communism was the way along which the fellow-locals community could be protected against a split between the clashing nationalisms, and against the related abasements. The biography of an UpperSilesian that J. Chałasiński has once quoted is worth recalling: the man considered Upper Silesia his homeland, seeing "the only solution to the Silesian issue ... in the communism as commenced in Russia"39. Dr Nicolai, Director of a department at the Reich's Ministry of Interior, might have some arguments to raise when he wrote that Poles belong to a race that can be named 'Bolshevik' (bolschewistische Rasse!). ${ }^{40}$

Referring to the considerations expressed in the initial section hereof, one has to conclude that in spite of its territorial character, the regional bond in Opole Silesia is founded in no clear concept of region as a territorial unit. Regional homeland, or fatherland, has no clearly delineated borderline, or is, rather, a blend of several areas of which each is connected with some cultural elements of the regional community, and some elements of tradition.

There is, after all, the Piast Silesia coming into play, encompassing Cieszyn and Opava, the Prussian Silesia with Wroclaw and Legnica, and the Upper Silesia, which forms one of the three Prussian Silesian regencies - the Opole Regency. Albeit administratively separated from the other regencies, Upper Silesia played a considerable part in the shaping of the regional homeland: it is with this regency that the notion of Upper-Silesian [Górnoślazak] is associated, which has become an ethnic idea and has penetrated into politics, particularly in Germany.

Of importance is also the plebiscite area, which does not extend to the whole of Opole Regency, its peculiar character having been developed not only through the stormy history of the preparations to the

${ }^{39}$ Józef Chałasiński, 'Antagonizm polsko-niemiecki w osadzie fabrycznej "Kopalnia” na Górnym Śląsku. Studium socjologiczne', Przegląd Socjologiczny, iii, 1-2 (1935), 79.

${ }^{40}$ Helmut Nicolai, Der Staat im nationalsozialistischen Weltbild (Neugestaltung von Recht und Wirtschaft, 1, Leipzig, 1934), 53. 
plebiscite but also through the fifteen years of the rule of the Geneva Convention laws (1922-37). The borderline which after the plebiscite divided Upper Silesia for eighteen years, generated the incipient traits of regional peculiarity in Opole Land, in opposition to the areas that were incorporated in the [Polish] Voivodeship of Silesia. With the plebiscite area being smaller than Upper Silesia within the former administrative limits, the territory of Catholic Silesia reached beyond the border of Upper Silesia, stretching to the County of Kłodzko. The said Catholic Silesia was not an abstract idea for the Upper-Silesians, since it was within Kłodzko County that the two important church fair locations, Wartha and Albendorf, were located, as we know. Owing to this circumstance, a certain form of regional liaison radiated to those Catholic counties [powiats] of the central Silesia.

Let us add that none of the areas enumerated here forms a region in an economic sense; none has a homogeneous character: in each of these areas, including the part of the plebiscite area allocated to Germany, a 'black' and 'green' Silesia can be found, in differing proportions. The regional community of Upper-Silesians is, thus, not territory-dependent; its reach is based not on geographical but on cultural factors, including: their own religion and language, which the Germans conscientiously distinguished from Polish, as a Wasserpolnisch, until 1939; their own moral and customs-related traits; and their own historical tradition, many hundred years old, since the Piast time, through the Great Fryc ['Fritz'; Frederick the Great], up to the plebiscite and the Silesian Uprising - a tradition that is associated with the regional territory, in its various forms.

The sense of group individuality is strengthened by the social position of this entire community, with its peculiar cultural features. In this respect, things look different in Opole Land than in the Silesian Basin; in particular, different than in 'Giełczyn' and the surrounding villages than in the settlement researched by J. Chałasiński in 1934. The settlement was a property of a German magnate and owner of industrial enterprises. ${ }^{41}$ There, in the villages on the Oder, without landowners or large-scale farmers, there was no room for acute class antagonisms, which were a powerful incentive behind the national antagonism in 'Kopalnia'. This is true at least with the people dealing with farming, trades and crafts, with whom we mainly had to do.

${ }^{41}$ Chałasiński, 'Antagonizm polsko-niemiecki'. 
But even there, it was known that a man holding a post would not be granted a 'progress' opportunity unless he gave himself out to be a German; it was known that changed surname paves the way open to certain posts, albeit for Upper-Silesians, even if they had their names replaced, these would never be high-ranking posts. It was known that the Germans formed the social elite, and looked down on the Slavonic populace; that the Upper Silesian accent in the German speech has a degrading effect. In the Provinz Posen resided Polish urban intelligentsia and Polish noblemen. Who spoke Polish there under the German rule, could even be a count. Polish, when spoken in Silesia, revealed its user's peasant or working-class background. The dwellers of 'Giełczyn' sensed the superiority of German culture. They did not protest when their names were entered in the documents in a German form, for it was just fine that way. As we have seen, some had German inscriptions made on tombstones, deeming it more elegant. Some German expressions used in conversations seemingly had a flavour to them similar to that of French phrases in the aspiring elegant circles of the Congress Kingdom.

Being shared by the local populace, the sense of being less valuable, and of cultural inferiority, was conducive to conservative attitudes in morals and customs, since compensation and protection against humiliation was sought in the 'values revered by the forefathers'. This common defence became a factor uniting the aboriginal community. Similar phenomena are observable in emigrant groups.

As Poles constituted over 80 per cent of the rural population in Opole County, whilst amounting to a mere 8 or 10 per cent of the Opole people, the culture connected with the Polish language in that area was a rural culture, to much a larger extent than in the Silesian Basin. Even those Polish patriots who, having gained an education, went away to towns, have never lost their support among the rural people. The rustic cultural patterns and a rustic universe of ideas were associated with the language. This would explain why a nun who had left 'Giełczyn' in her young years and spent afterwards thirty-five years of her life in Vienna, now, when back in her native village, begins using her family language and throws off herself the whole Viennese environment, together with the German speech, and uses expressions and images not being in harmony with her monastic frock or with the Viennese setting she had left behind. For instance, to depict the high quality of the fodder given to a horse, she 
would say, "if a cow was getting a futer [dial. feed] like this, she'd be shitting with butter".

Such inferiority complex could only be completely overcome through an ideology with which Polish background, rather than degrading, entitled one to undertake a commendable lifelong task, turning an individual, originally a representative of the peasant stratum, speaking a patois that the Germans scorned, into an exponent of a proud nation that cherishes [battles of] Grunwald and Psie Pole (Hundsfeld) as part of its historical heritage. Such was the ideology that turned the Silesian Wasser-Poles, German second- (or whatever-) class citizens, into the guard thrust westward, inheritors and defenders of the Piast heritage. The types of 'great Poles' were emerging along this path.

For the ambitious Polish worker, there was still another way to overcome the inferiority complex: the socialist ideology furnished him with a mission of the proletarian, a militant fighting for a better world. This path was tempting particularly in those working-class milieus where the class split did not coincide, be it roughly, with the nationality division, where Polish workers have their German associates. For landlords in an Opole village, standing in defence of his personal dignity and of the local community's own dignity, led to a national ideology. For some most eminent individuals, posts with the Association of Poles could be taken into account: a risky option, at times, but a reputable one, respected by the local milieu as well as by top-ranking Poles in Warsaw. For some others, the attitude of 'great Pole' was assumed despite any practical prospects and, in the later interwar period, despite any hope. One was a Pole 'for the sake of honour'; this attitude I have consequently named a select stance.

XIII

NEW PROCESSES, NEW ISSUES TO CONSIDER

In the mining settlement researched once by J. Chałasinski, after the plebiscite, the manager, a German, was carried away by the workers with wheelbarrows into a nearby pit. ${ }^{42}$ In 'Giełczyn', after the invasion of German troops and after the entry of Polish authorities, there was no-one to be carried out by barrows. All those Germans who would

42 Ibidem, 29. 
have been threatened by such developments, all those who had their reasons to fear the hatred of their Polish neighbours, fled together with the German troops, or even earlier than that.

Had they not escaped, - 'Marczyk' says - we would've taught'em a lesson! They would've understood what it means: they would work two days in a week for the State free of charge, and four days for money. They'd pay a 20 per cent higher tax.

This is an instance of practical retaliation - a light one, really, given that this man was threatened with death by the Orgesh-men during the Uprising, visited in 1940 by the Gestapo, his house getting stuffed with bullets, and his brother killed in Auschwitz.

The other 'Giełczyn' locals felt no will to retaliate anymore by August 1945. The Polish-German antagonism was only reminisced by the 'great Poloks'; what remained was an awareness of sinister hazard, which had actually been with them for so many years; but the maxims they sometimes uttered: "Germanics, villains they are in disguise", or "Germanics are kłaks, to live with'em you can't manage", came across no emotional response in the village in August 1945. Instead, they brought back some good Germans with whom one could get on in a neighbourly fashion. There was no "absolute opposition between Germanness and Polishness” in 'Giełczyn', as otherwise met one day by the author of 'Antagonizm polsko-niemiecki w osadzie fabrycznej "Kopalnia"'. ${ }^{43}$ German the enemy was replaced by Hitlerite - a real Nazi, not one of those "innocently drawn into the partai" or those who had joined it out of stupidity. Among such genuine Nazis, Poles, dissenters from their native milieu, happened to appear; a Nazi, or Hitlerite, was not the same as a German.

In any case, resulting from the developments I have described above, and from the disappointments caused by the newcomers, the old conflicts have become insignificant, old stereotypes grew pale. With the active Nazis escaping, and other Germans getting displaced, the validity of Polish-German relations expired at all.

With the shock of the last months behind them, the dwellers of 'Giełczyn' faced the issue of getting involved in the relations arranged anew, with no room available for Germans anymore. The new reality brought along its new categories.

${ }^{43}$ Ibidem, 60-1. 
Referring to the adjectival and nominal sense of the term 'Pole', the nominal aspect of the word is presently split but more specific: 'Pole' has become a noun signifying member of either of the strictly defined groups among the 'Giełczyn' locals. Two categories of Poles have appeared, each having grown tinged with a class, or estate, aspect, in a sense. Being a member of either is no more a matter of one's subjective creed or ethical qualification, but of a social situation; one of the two different social situations, to be specific.

One category, the privileged one, is Poles the newcomers. It is privileged as the Polish identity of these people has not been liable to verification and, the local inhabitants believe, they enjoy trust and support from the authorities. The other category is Poles having been subject to verification: the local, second-class Poles. But they also are privileged, in a way - compared to those not deemed Polish at all.

The privileged status being referred to is not reduced to the imponderables. Not only social prestige is the case but also the quite concrete and significant economic privileges. The split of the people into three categories corresponded with a variety of proprietorship rights. The property rights of those inhabitants who have not been granted Polish citizenship was limited to certain personal belongings, the remainder of their property remaining in their possession only temporarily, until deported. The verified Poles have retained their property. The repatriates and settlers from the former Polish territory were allocated the properties of the displaced, apartments and household effects in the first place. Since membership in both specified groups was regulated by the law, one could trace analogies with the estate-based, rather than class-based, social arrangement. The significance of this group hierarchy has, for the time being, obscured the class relationships of yore. ${ }^{44}$

The cultural discrepancies in relation to the newcomers, impossibility to communicate and comprehend each other on a deeper level, non-orientation of these comers as to the local conditions, ${ }^{45}$ mutual mistrust and, on the other hand, the hardships of the recent years and

${ }^{44}$ This description, let me stress, concerns the state of affairs as of August 1945. Serious changes have taken place ever since, which I do not cover herein. In June 1947, some settlers complained to me that the administration authorities were favouring the autochthons.

${ }^{45}$ The newly arriving Polish officials have committed a series of fatal errors due to their ignorance of the social life realities in Silesia. 
months experienced by the former residents of 'Giełczyn' and, presently, a shared social situation across the group hierarchy: all these factors entailed, of necessity, a reinforcement of the bond associating the local people. This stronger junction among the mutually familiar people in the summer of 1945 was of a defensive nature. Its substrate was, continually, a sense of inferiority: under the German rule, they were 'those of a worse sort', as those of Polish origin. Today, being part of the Polish society, they are those worse ones again, as the people intoxicated with the German language; thus, they are to be classed second again. The admixture of German words brands their speech with a degrading stigma, as once the Slavic accent added up a degrading mark, in certain cases, to their German.

A sense of powerlessness and uncertainty completed the picture. The complaint 'Marczyk' once wrote against the wicked wójt, apparently condemned by all his fellow villagers, was not signed by anyone else, save for its author. In the neighbouring village, the settlers from Lvov area who organised a self-defence network against marauders and installed alert gongs, complain about the passiveness and bashfulness of the local people who otherwise are so active with respect to ordinary routine chores at their farmsteads.

The state of affairs I have attempted at outlining here is, clearly, a point of departure for social processes of varied sorts. These processes encompassed crystallisation of a new system of social relations after the upheaval that transformed the reality in the land on the Oder River so fundamentally, with various systems and values represented by different groups of people colliding. These processes are worth being observed by researchers; also, they are worth of interest from those busy planning a novel Poland.

Two groups of people with different traditional background, descent and social attitudes came into touch with each other in the area by the Oder. Those who had been settled there since the Piast rulers' time came across those newly coming, from behind the Bug. We have seen the first phase of their contact. What we have also seen is a malevolent image of each of the groups, which has been getting formed in the other group's awareness. How will their mutual relations further develop? Will both groups be living beside each 
other as two deferent communities with their peculiar cultures, or will a united community emerge some day? What factors or drivers will be crucial to overcoming the persistent antagonism? What will be the pace this transition will assume? What sort of a cultural alloy will resultantly ensue? What role in the shaping of the future community, or local society, will the land on the Oder and its related traditions play? To what extent will the school(s) due to educate the children from both groups prove decisive in these developments?

Resulting from the reshaped frontier of the Polish Republic and from the demographic changes taking place on an unprecedented scale, the regional community of the ethnic borderland has ceased to be a frontier community. It has been separated from the German national territory by a wide strip of population resettled from central Poland or the eastern borderland. What sort of a metamorphosis in the social attitudes of Opole-Land Silesians may be expected to occur as a result of their having been relocated into the Polish national territory, together with their regional fatherland?

What course will be taken by the process of the regional community's striking root in the broad Polish community in the period of deep social and economic transformations? Will the sense of being put at a disadvantage be overcome, along with the 'estate-based' hierarchy founded upon one's originally coming from this or that side of the border? Will the sense of inferiority cease being the foundation of association within the aboriginal groups? And, what shape will the regional bond, with an age-old tradition behind it, assume then?

The questions of this kind, interesting for a sociologist and momentous for those constructing the new Poland - come to one's mind today, while thinking of the transformations taking place in the land of Silesia. Encountering the settlements on the Oder once again someday, we may find that the problems are changing together with the reality that produces them.

April 1947

Following my expectation expressed in the conclusion of this article, I had an opportunity to reencounter Silesia and its dwellers in June 1947. This time, I was accompanied in this follow-up research in 'Giełczyn' and its surrounding area by the Warsaw University's 
Assistant Lecturers Dr Stefan Nowakowski, Jan Strzelecki, and Marcin Czerwiński.

I have used the opportunity to ascertain that field research carried away once again at the same locality is quite instructive for a sociologist, given the present-day time of fast social transition.

Now, using the opportunity of my article remaining unformatted, I could, once back home, make therein some petty modifications, staying, in terms of content, within the limit of August 1945. In this respect, my encounter with the leader of local insurgents was of value to me. This man, who had led his troop out of 'Giełczyn' to involve it in the Third Uprising, now has let me use his valuable archives.

In the course of our research done this June, we were primarily interested in the transformations taking place within the local community since August 1945. This subject matter will probably be covered by one of our team in a separate study.

September 1947

trans. Tristan Korecki

The article was published in Polish under the title: 'Zagadnienia więzi regionalnej i więzi narodowej na Śląsku Opolskim’, Przegląd Socjologiczny, ix, 1-4 (1947), 73-124. 